\title{
The Role of Prosodic Breaks and Pitch Accents in Grouping Words during On-line Sentence Processing
}

\author{
Sara Bögels ${ }^{1}$, Herbert Schriefers ${ }^{1}$, Wietske Vonk ${ }^{1,2}$, \\ and Dorothee J. Chwilla ${ }^{1}$
}

\begin{abstract}
The present study addresses the question whether accentuation and prosodic phrasing can have a similar function, namely, to group words in a sentence together. Participants listened to locally ambiguous sentences containing object- and subjectcontrol verbs while ERPs were measured. In Experiment 1, these sentences contained a prosodic break, which can create a certain syntactic grouping of words, or no prosodic break. At the disambiguation, an N400 effect occurred when the disambiguation was in conflict with the syntactic grouping created by the break. We found a similar N400 effect without the break, indicating that the break did not strengthen an already existing preference. This pattern held for both object- and subject-control items. In Experiment 2, the same sentences contained a break and a pitch accent on the noun following the break. We argue that the pitch accent indicates a broad focus covering two words [see Gussenhoven, C.
\end{abstract}

\section{INTRODUCTION}

Prosody is an aspect of language that is available explicitly only in spoken utterances. The present study investigates whether two prosodic devices, prosodic phrasing and accentuation, can group words in sentences together during on-line language processing. In research on the role of prosodic phrasing in auditory sentence processing (e.g., Kjelgaard \& Speer, 1999; Pynte \& Prieur, 1996; Warren, Grabe, \& Nolan, 1995), the general idea is that prosodic breaks can indicate where syntactic breaks occur in a sentence, and thus, affect on-line sentence processing. A prosodic break or boundary (PB) consists of a pause, and prefinal lengthening and a boundary tone on the word preceding the pause (e.g., Kjelgaard \& Speer, 1999). ERP studies have shown that syntactic processing can be affected by PBs (e.g., a PB can disambiguate a locally ambiguous sentence; Bögels, Schriefers, Vonk, Chwilla, \& Kerkhofs, 2010; Kerkhofs, Vonk, Schriefers, \& Chwilla, 2008; Steinhauer, Alter, \& Friederici, 1999) as well as by left-edge boundary tones (Roll, Horne, \& Lindgren, 2009, 2011) and by sentence-end intonation (Eckstein \& Friederici, 2005, 2006). Prosodic phrasing, for example by

\footnotetext{
${ }^{1}$ Radboud University Nijmegen, Netherlands, ${ }^{2}$ Max Planck Insti-
} tute for Psycholinguistics, Nijmegen, Netherlands
On the limits of focus projection in English. In P. Bosch \& R. van der Sandt (Eds.), Focus: Linguistic, cognitive, and computational perspectives. Cambridge: University Press, 1999], thus grouping these words together. For object-control items, this was semantically possible, which led to a "good-enough" interpretation of the sentence. Therefore, both sentences were interpreted equally well and the N400 effect found in Experiment 1 was absent. In contrast, for subject-control items, a corresponding grouping of the words was impossible, both semantically and syntactically, leading to processing difficulty in the form of an N400 effect and a late positivity. In conclusion, accentuation can group words together on the level of information structure, leading to either a semantically "good-enough" interpretation or a processing problem when such a semantic interpretation is not possible.

a $\mathrm{PB}$, thus can provide information about the syntactic structure of a sentence.

In contrast, accentuation has been mostly studied in relation to information structure. The distribution of pitch accents in a sentence can indicate which information is new, and which information is already mentioned, that is, given. Dahan, Tanenhaus, and Chambers (2002), for example, used the visual world paradigm to show that accented nouns lead to early fixations on a new object, whereas unaccented nouns lead to early fixations on an already mentioned object (see also, e.g., Birch \& Clifton, 1995). This issue has also been addressed using ERPs, showing processing difficulties when listeners encounter missing accents on new words and/or superfluous accents on given words (e.g., Heim \& Alter, 2006, 2007; Toepel, Pannekamp, \& Alter, 2007; Magne et al., 2005; Hruska \& Alter, 2004; Johnson, Clifton, Breen, \& Morris, 2003; see also Stolterfoht, Friederici, Alter, \& Steube, 2007 for ERP effects on implicit prosody during reading).

The emerging picture suggests that prosodic phrasing can signal syntactic boundaries, whereas accentuation can indicate which information is new and should thus be in focus. These seem to be clearly different functions. As a result, research on the role of prosodic phrasing and research on the role of accentuation in sentence processing have 
developed quite independently. However, in the present study, we argue that in a certain respect, both prosodic devices might also serve a similar function, namely, to indicate which words in a sentence belong together more closely than others.

With respect to accentuation, a closer look at the linguistic literature on the relation between accentuation and focus shows that an accent on a given word does not necessarily define only this specific word as being in focus. Rather, under certain circumstances, the focus induced by an accent on a given word can be wider than this word, that is, the focus can spread out to adjacent lexical elements. Let us refer to (1) and (2) for examples (see Gussenhoven, 1999):

(1a) Who died?

(1b) What happened?

(2) JOHNson died.

The question in (1a) leads to a focus only on the word Jobnson in the answer in (2) as the verb died is mentioned in the question and is thus given. In contrast, the question in (1b) is more general, and thus, all elements of the answer (2) provide new information and should be in focus. Nevertheless, answer (2), with only an accent on Johnson, is also a correct answer to the wide focus question in (1b) (as would be an answer in which both elements are accented). Thus, it appears that the accent on Johnson can not only signal a narrow focus for this specific word, but also a wide focus consisting of Johnson and the unaccented verb died.

Gussenhoven (1999) explains this observation with the Sentence Accent Assignment Rule (SAAR). SAAR states that an accent on a certain noun (such as Jobnson in 2) can not only lend focus to this accented noun, but also to an adjacent unaccented predicate of which it is an argument (i.e., died in 2). In the case of such a wide focus consisting of more than a single word, a pitch accent on a word groups two or more words together in terms of information structure. Note that SAAR is a descriptive linguistic account of accentuation. It provides a rule of how to assign accents to elements in a sentence, when it is known which elements should be in focus and which syntactic relations exist between these elements. No explicit statements are made about what happens in online, left-to-right sentence processing. If one extrapolates SAAR to sentence processing, one can hypothesize that an accented argument and an adjacent unaccented predicate are grouped together by the listener as a verb and its argument, provided the listener assumes a broad focus spanning both words.

From this perspective, PBs and pitch accents can serve a similar function. They both signal which words belong together more closely than others, although at different levels: PBs at the level of syntactic structure, and pitch accents at the level of information structure. In the present study, we will address the question whether PBs and accents do have such a similar function in on-line processing of auditorily presented sentences.

If these devices indeed have such a grouping function, they should affect the processing of locally ambiguous sentences like the Dutch sentences in (3) and (4) (LT: literal, word-by-word English translation; T: English translation). These constructions have been used previously to study the role of PBs in sentence processing (e.g., in German, by Steinhauer et al., 1999) and the same stimuli (in Dutch) were used by Bögels et al. (2010).

(3) De chirurg (NP1) adviseerde (V1) de vrouw (NP2) te slapen $\left(\mathrm{V} 2_{\text {intransitive }}\right) \ldots$

LT/T: The surgeon (NP1) advised (V1) the woman (NP2) to sleep ( $\left.V 2_{\text {intransitive }}\right)$..

(4) De chirurg (NP1) adviseerde (V1) de vrouw (NP2) te ondersteunen $\left(\mathrm{V} 2_{\text {transitive }}\right) \ldots$

LT: The surgeon (NP1) advised (V1) the woman (NP2) to support (V2 transitive)...

$\mathrm{T}$ : "The surgeon (NP1) advised (V1) [someone] to support (V2 transitive) the woman (NP2)."

Note that, in contrast to English, in (4) the indirect object of V1 (advised) can be left implicit in Dutch. This implicit indirect object is indicated by [someone] in the English translation. Furthermore, the word order of the last two constituents in (4) is reversed in Dutch as compared with English. Therefore, in Dutch, (3) and (4) are ambiguous up to the disambiguating verb, V2. In (3), V2 (to sleep) is obligatorily intransitive, and thus NP2 (the woman) has to be indirect object of V1 (advised). In contrast, in (4), V2 (to support) is obligatorily transitive, and thus, NP2 is the direct object of V2. A PB after V1 can separate $\mathrm{V} 1$ and NP2, thereby blocking an interpretation in which NP2 is the indirect object of V1. This should lead to problems at the intransitive disambiguating verb in (3), but not at the transitive disambiguating verb in (4). In the ERP study by Bögels et al., a PB after V1 indeed led to an N400 effect at an intransitive disambiguating verb (as in 3) relative to a transitive disambiguating verb (as in 4), whereas no difference was found when the PB was absent. However, this was only found for so-called objectcontrol items as in (3) and (4). In these sentences, V1 (advise) is called an object-control verb because its (indirect) object is the understood subject of the later verb, V2. In (3), the indirect object of V1 (NP2, the woman) is also the understood subject of V2; the woman should sleep. In contrast, in (4), the indirect object of V1 is left implicit. However, it is clear that this implicit indirect object is also the understood subject of V2; the person(s) receiving the surgeon's advice should also support the woman. This is different in so-called subject-control items, such as (5) and (6).

(5) De leerling (NP1) bekende (V1) de leraar (NP2) te hebben gespiekt $\left(\mathrm{V} 2_{\text {intransitive }}\right)$...

LT: The pupil (NP1) confessed (V1) the teacher (NP2) to have cheated (V2 intransitive)... 
T: The pupil (NP1) confessed (V1) to the teacher (NP2) to have cheated ( $\left.V 2_{\text {intransitive }}\right) .$.

(6) De leerling (NP1) bekende (V1) de leraar (NP2) te hebben opgesloten $\left(\mathrm{V} 2_{\text {transitive }}\right) \ldots$

LT: The pupil (NP1) confessed (V1) the teacher (NP2) to bave locked up (V2 transitive)...

T: "The pupil (NP1) confessed (V1) to have locked up (V2 transitive) the teacher (NP2)."

In these sentences, V1 (confess) is called a subject-control verb because its subject (the pupil, NP1) in both (5) and (6) is also the understood subject of V2 (to lock up or to cheat) (see Comrie, 1985 for a discussion of subject- and objectcontrol verbs). For subject-control items, Bögels et al. found an N400 effect for the intransitive relative to the transitive V2, but this N400 effect was present both in sentences with and without a PB. This result suggests that a general preference for a transitive disambiguating verb exists in these subject-control items. This preference thus guides listeners in the same direction as the PB would.

The present experiments focus on the question whether not only prosodic phrasing but also accentuation can affect the grouping of words in sentences. To investigate this question, we first manipulate the presence of a $\mathrm{PB}$ alone (Experiment 1), as in Bögels et al. (2010). The motivation for this replication is twofold. First, the comparison of an off-line sentence completion task (Bögels et al., Experiment 1) with on-line ERP results (Bögels et al., Experiment 2) showed that the general preference for a transitive or intransitive disambiguation in these sentences is relatively unstable. Second, the filler sentences in the ERP experiment of Bögels et al. contained a manipulation of the presence versus absence of a $\mathrm{PB}$, which might have led participants to pay special attention to PBs. In the present Experiment 1, we replace these filler sentences by filler sentences without a manipulation of the presence versus absence of a PB. Despite this change, we expect to replicate the results of Bögels et al. in terms of ERP results, especially regarding the conditions with a PB.

In Experiment 2, a pitch accent on NP2 is introduced, in addition to the PB after V1. This is pitted against a situation where both PB and pitch accent on NP2 are absent. As we argued above, on the basis of SAAR (Gussenhoven, 1999), such a pitch accent on NP2 can project focus to an adjacent predicate in a broad-focus situation. Because the sentences are presented in isolation (as in Bögels et al., 2010), we assume that listeners will indeed adopt a broad focus; a narrow focus on only the accented element (i.e., NP2 in Experiment 2) would require a context in which the other elements are given.

For the focus projection of the accented NP2 to an adjacent predicate, there are two options. The first option would be for NP2 to project its focus to the preceding predicate, V1. However, the PB between V1 and NP2 should indicate that NP2 is not an argument of V1 (see Bögels et al., 2010). The second option is that the ac- cented NP2 lends focus to the following (unaccented) predicate, V2, thus grouping NP2 and V2 together. This grouping, however, can only succeed if NP2 can be interpreted as an argument of V2.

Because subject- and object-control items differ with respect to the understood subject of V2 (see above), we derive the hypotheses for these two types of sentences separately. For object-control items (see 3 and 4 ), a transitive V2 as in (4) (to support) should pose no problem because NP2 (the woman) can be incorporated as an argument of support, that is, as its direct object. In (3), V2 (to sleep) is intransitive, and thus, NP2 cannot be its object. Furthermore, syntactically, the infinitival clause (to sleep) has no overt subject. If listeners only regard the sentence in such a syntactic way, they will conclude that NP2 (the woman) cannot be an argument of sleep (V2), and therefore, get into problems when encountering this V2 following an accented NP2. However, inspecting the semantics of the sentence more closely, NP2 is the understood subject of V2 (i.e., the woman should sleep). In other words, NP2, the indirect object of the main clause, controls the reference of the understood subject of V2, hence, the term "object-control" (see Comrie, 1985, pp. 47-48). Therefore, semantically, the woman (NP2) can be interpreted as an argument of sleep (V2), namely, as its understood subject. If listeners process the sentences in such a semantic way, the broad-focus interpretation of the accent on woman (NP2) would fit both support (the transitive V2 in 4) and sleep (the intransitive V2 in 3). In terms of ERP results, the additional accent on NP2 in Experiment 2 should thus lead to additional processing costs for an intransitive relative to a transitive V2 when listeners adhere to a strict syntactic analysis. However, when they take into account the semantics of the broad-focus interpretation of an accented NP2, no additional processing costs are expected.

For subject-control items, a transitive V2 in (6) (to lock up) again poses no problem, as the accented NP2 (the teacher) is V2's direct object, fitting a broad-focus interpretation. In (5), however, NP2 (the teacher) is not a possible argument for the intransitive V2 (to cheat): neither as its object, because V2 is intransitive, nor as its understood subject. Therefore, neither syntactically nor semantically does the intransitive V2 fit with the broad-focus interpretation of an accented NP2. In terms of ERP results, this should lead to additional processing costs relative to a transitive verb. As there is, to our knowledge, until now no ERP study on this issue, we refrain from predictions in terms of the specific ERP signature of this potential additional processing cost. Likely options are a quantitative difference, such as a larger N400 effect, or a qualitative difference, such as an additional P600 effect.

Finally, in both experiments and for both types of items, we expect to replicate the finding of a closure positive shift (CPS), a positive-going ERP component, in response to the $\mathrm{PB}$, relative to the sentences without a PB (e.g., Bögels et al., 2010; Steinhauer et al., 1999). 


\section{EXPERIMENT 1}

\section{Methods}

\section{Participants}

Participants were 43 right-handed native speakers of Dutch without hearing problems, who received $€ 8$ per hour or course credit for their participation. All participants were students at the Radboud University Nijmegen. Fifteen participants were excluded from analysis because of excessive artifacts, mainly due to eye blinks. The remaining 28 participants ( 20 women, 8 men) had a mean age of 21.7 years (range $=18-26$ ).

\section{Materials}

The experimental materials were slightly adapted from Bögels et al. (2010) (see Appendix A for the complete list of experimental items). Table 1 gives examples of the two types of experimental items (object-control items and subject-control items) in the four experimental conditions. The first verb (V1) in each sentence is a so-called control verb. In object-control items, the indirect object of the control verb (V1) is the understood subject of V2. In subjectcontrol items, the subject (NP1) of the control verb (V1) is the understood subject of V2. We used all suitable control verbs that are available in Dutch (10 object-control and
14 subject-control verbs). ${ }^{1}$ All verbs were used in two different items, leading to a total of 48 experimental items (20 object- and 28 subject-control items).

Each item occurred in the four Conditions A-D (see Table 1). V2 was either obligatorily intransitive (Conditions $\mathrm{A}$ and $\mathrm{B}$ ) or obligatorily transitive (Conditions $\mathrm{C}$ and D). Between V1 and NP2, a PB was present (Conditions A and $\mathrm{C}$ ) or absent (Conditions $\mathrm{B}$ and $\mathrm{D}$ ).

The auditory experimental materials were spoken by a female native speaker of Dutch and digitally recorded. She first read a written version of a sentence silently for herself and then read it out loud. She only produced the sentences in which the presence or absence of a PB was in line with the disambiguating transitive or intransitive V2 (B and C in Table 1), each three times. These recorded sentences were spliced at two positions, after NP1 and before the te ("to") of V2. The resulting three parts (NP1, V1 plus NP2, and the remainder of the sentence) were used to create the experimental conditions A to D. For each item, all four conditions contained the same token of NP1; in one half of the items NP1 was taken from a sentence with a PB and in the other half from a sentence without a PB. The second cross-spliced part (V1 plus NP2) was taken from one recorded token with a PB for Conditions $\mathrm{A}$ and $\mathrm{C}$ and from one recorded token without a PB for Conditions B and D. The last cross-spliced part

Table 1. Examples of Experimental Items

Object-control

A $\quad \mathrm{PB}$, intransitive V2

B

C

D no $\mathrm{PB}$, transitive $\mathrm{V} 2$

[De chirurg adviseerde] [de vrouw te slapen] [voor de zware operatie.] [The surgeon advised] [the woman to sleep] [before the heavy surgery.]

[De chirurg adviseerde de vrouw te slapen] [voor de zware operatie.] [The surgeon advised the woman to sleep] [before the heavy surgery.]

[De chirurg adviseerde] [de vrouw te ondersteunen] [voor de zware operatie.] [The surgeon advised] [the woman to support] [before the beavy surgery.] [De chirurg adviseerde de vrouw te ondersteunen] [voor de zware operatie.] [The surgeon advised the woman to support] [before the heavy surgery.] Subject-control

A

$\mathrm{B}$

C $\quad \mathrm{PB}$, transitive V2

D no $\mathrm{PB}$, transitive V2
[De leerling bekende] [de leraar te hebben gespiekt] [tijdens het eerste uur.] [The pupil confessed] [the teacher to have cheated] [during the first hour.] [De leerling bekende de leraar te hebben gespiekt] [tijdens het eerste uur.] [The pupil confessed the teacher to have cheated] [during the first bour.] [De leerling bekende] [de leraar te hebben opgesloten] [tijdens het eerste uur.] [The pupil confessed] [the teacher to bave locked up] [during the first bour.] [De leerling bekende de leraar te hebben opgesloten] [tijdens het eerste uur.] [The pupil confessed the teacher to bave locked up] [during the first hour.]

Intonational phrases, separated by PBs, are indicated by square brackets. Literal, word-by-word English translations are given in italics. For the English translations, see Examples 3 to 6 in the Introduction. 
(te until the end of the sentence) was taken from one recorded sentence with an intransitive disambiguating verb for Conditions A and B and from one recorded sentence with a transitive disambiguating verb for Conditions $C$ and D.

Furthermore, two different types of filler items were used in the experiment. One type consisted of 60 simple high or low cloze sentences (adapted from Hagoort \& Brown, 1994). The other type were 60 sentences containing locally ambiguous subject/object-relative clauses (adapted from Mak, Vonk, \& Schriefers, 2002). All filler items were recorded twice and cross-spliced. Also, 16 additional sentences of the same structure as the experimental sentences and 16 of the same structure as the filler sentences were recorded and cross-spliced. Twenty of these were used in a practice block before the experiment and 12 as starter sentences at the beginning of each of the six experimental blocks (see Procedure).

Acoustic analyses were performed on the experimental sentences to compare the conditions with and without a PB. Table B1 of Appendix B presents the measurements and statistical results of these analyses. Here, we only summarize the main results. Visual inspection revealed qualitative differences in the pitch track of V1 between sentences with and without a PB. In both object- and subject-control items with a $\mathrm{PB}$, a more or less pronounced pitch rise occurred on V1 before the pause. In sentences without a PB, a normal pitch accent or, in some cases, deaccentuation occurred on V1. The acoustic analyses revealed that V1 was lengthened in the $\mathrm{PB}$ conditions relative to the no PB conditions for both types of items. This lengthening occurred on all syllables but was most pronounced for the last stressed syllable of V1 and subsequent syllables. A pause was present between V1 and NP2 in the PB conditions, whereas no pause existed in the no PB conditions. NP2 had a slightly larger pitch range in the PB than in the no PB conditions for both types of items; in subjectcontrol items, this was compensated by a slightly longer duration of NP2 in the no PB condition. However, these differences on NP2 were all very small (see Appendix B). In all conditions, a pause occurred after V2.

\section{Design}

The experiment had two subdesigns, one for the objectcontrol items and one for the subject-control items. Both designs consisted of the two fully crossed factors PB (PB, no PB) and Structure (transitive V2, intransitive V2).

Four different lists were created. Each experimental item occurred in all four conditions in each list $(4 \times 20$ object-control items and $4 \times 28$ subject-control items $=$ 192 experimental items), but only once in each quarter of a list. The quarters in the four lists were counterbalanced in a Latin square design, such that across lists, each item occurred in all four conditions in each quarter. The conditions were counterbalanced within the lists and quarters in such a way that the conditions were distributed evenly over the quarters of the experimental lists. The 192 ex- perimental items and 120 filler items were intermixed in pseudorandom order. No more than three experimental or two filler items occurred in a row. The 312 sentences in each list were divided in six blocks of 52 sentences.

\section{Procedure}

Participants read an instruction to listen to the sentences for comprehension and to try to imagine what the sentences were about. Sentences were presented over headphones. A trial started with a 50-msec warning beep, followed by $450 \mathrm{msec}$ of silence (with background noise from the recording) and the sentence. There was a 4000-msec interval between the end of a sentence and the next warning beep. The participants were instructed to restrict eye blinks to the beginning of this interval and to look at a fixation cross on a computer screen during the presentation of a sentence. This was trained during a practice block of 20 sentences, which was repeated if necessary. Then, the six experimental blocks of 52 sentences each were presented, each preceded by two starter sentences.

After each block, the participants received a sentence recognition task. They had to indicate which of two written sentences had appeared in the previous block. This task ensured that attention was paid to the sentences. After this task, participants could take a short break before continuing.

\section{Apparatus}

EEG was recorded from 25 tin electrodes. Electrode positions were a subset of the International 10-20 System, consisting of three midline electrodes (Fz, Cz, and $\mathrm{Pz}$ ) and 22 lateral electrodes (AF7/8, FT7/8, F7/8, F3/4, FC3/4, T7/8, C3/4, CP5/6, P7/8, P3/4, and PO7/8). This montage has been used in earlier auditory ERP studies (Bögels et al., 2010; Kerkhofs, Vonk, Schriefers, \& Chwilla, 2007). During the recording, the left mastoid served as reference, but rereferencing to the average of both mastoids occurred before the analysis. Vertical EOG electrodes above and below the right eye, and horizontal EOG electrodes at the outer canthi were used to monitor eye blinks and eye movements. Impedance was kept below $5 \mathrm{k} \Omega$ for the EOG electrodes and below $3 \mathrm{k} \Omega$ for the EEG electrodes. EEG and EOG signals were amplified with a time constant of $8 \mathrm{sec}$ and a band-pass filter of 0.05 to $100 \mathrm{~Hz}$ and were digitized with a 16-bit A/D converter at a sampling frequency of $500 \mathrm{~Hz}$.

\section{Data Analysis for ERP Data}

The EEG data were first low-pass filtered with $30 \mathrm{~Hz}$. Epochs were extracted for two different positions in the sentence, for the $\mathrm{PB}$ and for the disambiguating region (V2). For the PB, averages were computed from $150 \mathrm{msec}$ before until $2000 \mathrm{msec}$ after the onset of the last stressed syllable of V1, because at this position, the prefinal lengthening 
and the boundary tone start in the PB condition. This time-locking point, therefore, provides a good compromise between too much jitter between items in the onset of the pause of the $\mathrm{PB}$ (which would occur choosing sentence onset as time-locking point) and taking into account only the pause and no other components of the PB (which would occur choosing pause onset) (see Bögels et al., 2010 for a direct comparison of these time-locking points). We collapsed the data over the two levels of Structure (intransitive and transitive) for this time-locking point because the sentences in these two conditions did not differ up to the disambiguating region (i.e., V2). For V2, averages were computed from $150 \mathrm{msec}$ before until $1000 \mathrm{msec}$ after its onset. The first $150 \mathrm{msec}$ was used as a baseline. Epochs containing excessive EEG $(>100 \mu \mathrm{V})$ or EOG $(>75 \mu \mathrm{V})$ amplitudes were excluded from the analyses.

The preprocessed data were analyzed as follows. For the first time-locking point (PB), a time window of 8001200 msec was chosen for analysis of the CPS (based on the results by Bögels et al., 2010), and for the second time-locking point (disambiguating verb), the standard N400 time window of 300-500 msec was used. Other time windows were chosen on the basis of visual inspection of the grand-average waveforms and time-course analyses of consecutive $100 \mathrm{msec}$ windows. Separate analyses were performed for the object- and subject-control items. Critical factors were $\mathrm{PB}(\mathrm{PB}, \mathrm{no} \mathrm{PB})$ for the time-locking point of the PB (onset of stressed syllable of V1), and PB and Structure (intransitive, transitive) for the time-locking point of the disambiguating verb (onset of V2). For the midline electrodes, a repeated measures MANOVA was performed with the critical factor(s) and the factor midline Electrode (Fz, Cz, Pz). For the lateral electrodes, the repeated measures MANOVA included the critical factor(s) and the factors Hemisphere (left, right), ROI (anterior, posterior), and Electrode (4 levels). Only interactions including a critical factor are reported. The factors Hemisphere and ROI divided the electrodes into four ROIs with four electrodes in each region (left anterior: AF7, F7, F3, FC3; right anterior: AF8, F8, F4, FC4; left posterior: $\mathrm{CP} 5, \mathrm{P} 3, \mathrm{P} 7, \mathrm{PO} 7$; right posterior: $\mathrm{CP} 6, \mathrm{P} 4, \mathrm{P} 8, \mathrm{PO} 8)$. This leaves six mid-lateral electrodes out of these analyses. If the distribution of an effect could not be shown via analyses of the separate ROIs and there were effects including the factor Electrode, separate analyses for all single electrodes were performed. The grand-average waveforms presented in the figures were smoothed using a 5-Hz low-pass filter. This additional filtering was not applied to the data entering the statistical analyses.

\section{Results}

\section{Sentence Recognition Task}

Out of the 28 participants, 27 correctly identified the sentence that they had heard from the two presented sen- tences after all six experimental blocks. One participant made one error.

\section{ERPs to Prosodic Break}

For the analyses of the CPS, after artifact removal, a mean of 36 trials (range $=24-40$ trials, $S D=3.6$ ) remained per condition for object-control items, and a mean of 50 (range $=42-56$ trials, $S D=4.0$ ) for subject-control items, with no significant differences between conditions. Figure C1, Panel I of Appendix C presents grand-average waveforms at the midline electrodes for the $\mathrm{PB}$ and no $\mathrm{PB}$ conditions of the object- and subject-control items, time locked to the onset of the stressed syllable of V1 (just before the pause of the PB). Table C1 of Appendix $\mathrm{C}$ shows the relevant results from the statistical analyses. For reasons of space, we only report the main conclusions of these analyses here. Both types of items showed a broad and robust CPS with a similar, somewhat right-lateralized distribution. Furthermore, the object-control items showed a negativity preceding the CPS that was broadly distributed across the scalp.

\section{ERPs to Disambiguating Verb}

For the analyses at the disambiguating verb, after artifact removal, a mean of 19 trials (range $=16-20$ trials, $S D=$ 0.9) per condition remained for object-control items, and a mean of 27 (range $=24-28$ trials, $S D=1.1$ ) for subjectcontrol items, with no significant differences between conditions. Figure 1 displays grand-average waveforms for a relevant subset of electrodes, time locked to the onset of V2 for all four experimental conditions, separately for object-control items (A) and subject-control items (B). Visual inspection suggests an N400-like effect for the intransitive conditions relative to the transitive conditions. At most electrodes, this effect seems to be prolonged up to $700 \mathrm{msec}$. This was confirmed by time-course analyses of consecutive 100 msec windows. Therefore, in addition to the standard $\mathrm{N} 400$ window, we also analyzed the mean amplitudes for the 500-700 msec window. Throughout, we do not report main effects of $\mathrm{PB}$ as these can be caused by confounds from the earlier presence or absence of a $\mathrm{PB}$ in the sentence.

The midline analysis for the object-control items yielded a main effect of Structure for the early (300-500 msec) window $[F(1,27)=7.58, p<.05]$, but no effects for the late $(500-700 \mathrm{msec})$ window ( $p s>.06)$. For the early window, the lateral analysis showed a main effect of Structure $[F(1,27)=5.36, p<.05]$ and interactions between Structure, ROI, and Electrode $[F(3,25)=3.64, p<.05]$ and between Structure and Electrode $[F(3,25)=3.50, p<.05]$. For the late window, this analysis yielded a four-way interaction between Structure, Hemisphere, ROI, and Electrode $[F(3,25)=4.00, p<.05]$. Follow-up analyses for the early window revealed that the effect of Structure, reflecting a 
Figure 1. Grand-average waveforms time locked to the onset of the disambiguating verb (V2) in Experiment 1 (for a subset of electrodes), for the object-control items (A) and the subject-control items (B), for the four different conditions. Both panels show an N400 effect for both intransitive conditions relative to their corresponding transitive conditions.

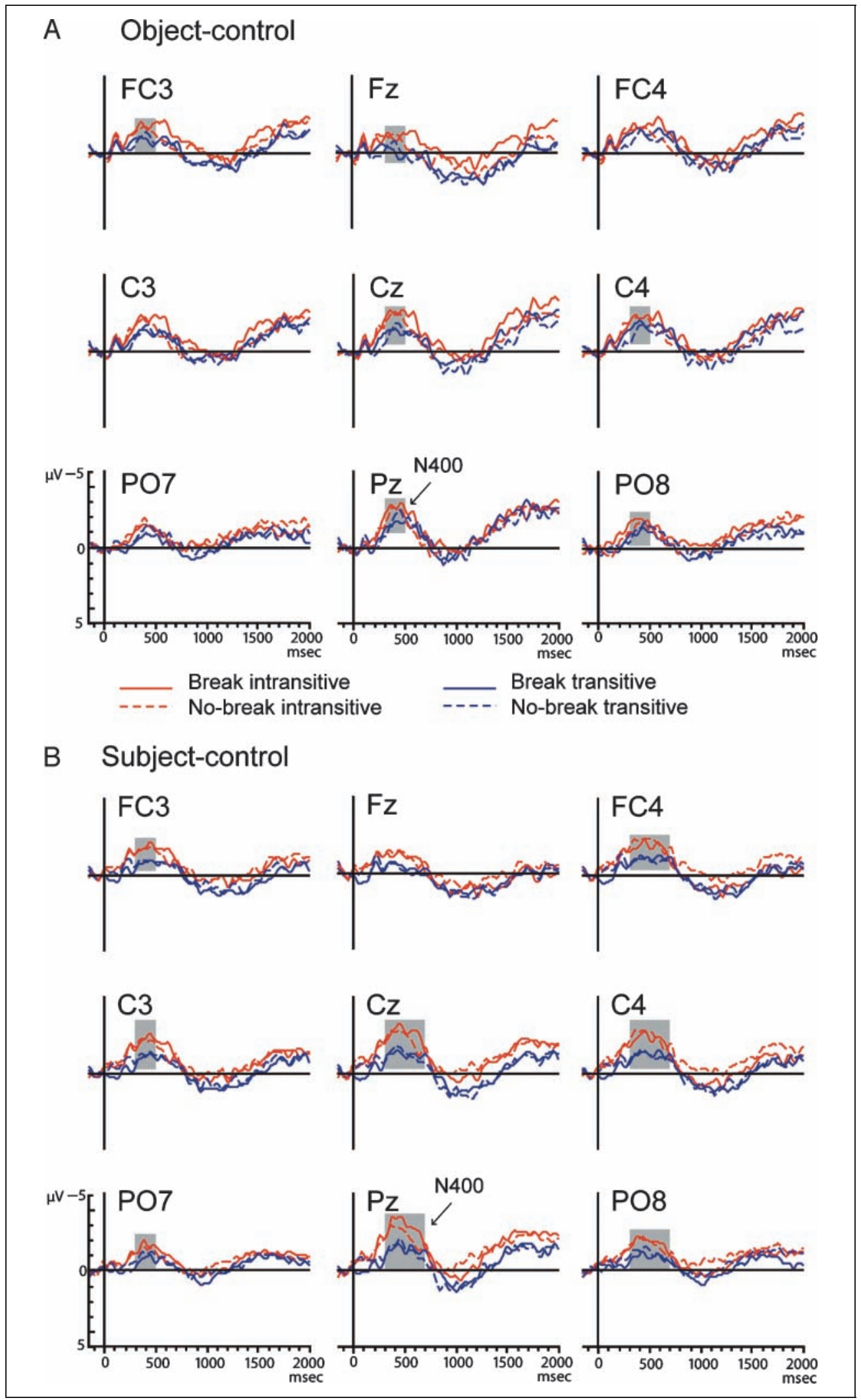

larger N400 for an intransitive V2 than for a transitive V2, was present over the central, right posterior, and some left anterior electrodes. For the late window, no reliable effects were found (all $p s>.09$ ).
The midline analysis for the subject-control items yielded a main effect of Structure for both the early $[F(1,27)=$ $13.98, p<.001]$ and the late window $[F(1,27)=7.35$, $p<.05]$. For the early window, the lateral analysis showed 
a main effect of Structure $[F(1,27)=14.49, p<.001]$ and a Structure $\times$ Electrode interaction $[F(3,25)=4.01, p<.05]$. For the late window, a main effect of Structure $[F(1,27)=$ $6.12, p<.05]$ and a Structure $\times \mathrm{PB} \times$ Hemisphere interaction $[F(1,27)=8.92, p<.01]$ were found. However, follow-up analyses did not reveal a Structure $\times$ PB interaction for any of the single electrodes (all $p$ s $>.07$ ). The main effect of Structure, that is, a larger N400 amplitude for the intransitive than for the transitive condition, was broadly distributed across the scalp, but was maximal at posterior electrodes for the early window. For the late window, the effect was mainly present centrally and over the right hemisphere. In sum, these analyses support a broadly distributed N400 effect for the intransitive as compared to the transitive V2 for object- and subject-control items.

\section{Discussion}

First, we replicated the finding of a CPS at the position of the $\mathrm{PB}$, which has been reported in numerous previous studies (e.g., Bögels et al., 2010; Steinhauer et al., 1999). The CPS was broadly distributed over the scalp with a tendency to be larger over the right hemisphere. Furthermore, a negativity preceding the CPS was present only for the object-control items.

At the disambiguating verb, V2, Bögels et al. (2010) found an interaction between Structure and PB for the object-control items, indicating that the N400 effect for intransitive V2s was present in the PB condition, but not in the no PB condition. The present experiment yielded a general intransitive N400 effect for the PB and no PB conditions. This difference between the present experiment and Bögels et al. suggests that for object-control items, listeners have a rather unstable preference for a transitive or intransitive disambiguating verb. This conclusion is in line with the divergence in results for the object-control items, as found by Bögels et al. between an off-line sentence completion task (Bögels et al., Experiment 1) and an ERP experiment (Bögels et al., Experiment 2). Due to this unstable preference, the processing of these sentences might be easily influenced by subtle external factors. For example, the current experiment and Experiment 2 of Bögels et al. used different filler items. In the latter study, the fillers also contained a manipulation of the presence of a PB, which could disambiguate the filler sentences, whereas the filler sentences of the present experiment did not contain a comparable manipulation. Therefore, the possibility to use the $\mathrm{PB}$ as a cue for disambiguation might have been emphasized by the filler sentences in Bögels et al., but not in the present experiment.

For the subject-control items, on the basis of the results by Bögels et al. (2010), a general N400 effect was expected for intransitive relative to transitive V2s, irrespective of the presence or absence of a PB. Indeed, we found a larger $\mathrm{N} 400$ at the intransitive than the transitive disambiguating V2, both for sentences with and without a PB. This N400 effect was broadly distributed over the scalp but was some- what larger for the posterior regions. The effect lasted longer than the standard 300-500 msec window and, for several electrodes, extended to the 500-700 msec time window. Such a longer duration of effects is typical for auditory presentation of language (Anderson \& Holcomb, 1995).

\section{EXPERIMENT 2}

Experiment 2, similar to Experiment 1, again contrasted items with and without a PB. However, the items with a PB were now realized with a pitch accent on NP2. As argued in the Introduction, the pitch accent on NP2 induces a broad focus, and thus, an attempt to analyze NP2 as an argument of V2. For subject-control items, this turns out to be impossible for an intransitive V2 as NP2 can neither be the subject nor the object of V2, which might lead to additional processing difficulty for the intransitive V2. In contrast, for object-control items, NP2 can be the syntactic object of a transitive V2 and the understood subject of an intransitive V2. Therefore, if listeners use a semantically plausible analysis, the pitch accent on NP2 should reduce or eliminate the ERP effects for intransitive V2s found in Experiment 1.

\section{Methods}

\section{Participants}

Participants were 33 right-handed native speakers of Dutch without hearing problems. All were students at the Radboud University Nijmegen. They received $€ 10$ per hour or course credit for their participation. Because of excessive artifacts, five participants were excluded from the analyses. The remaining 28 participants ( 24 women, 4 men) had a mean age of 20.1 years (range $=18-23$ ).

\section{Materials}

The materials consisted of the same items as in Experiment 1 (see Table 1 for examples), except for a few changes (see Appendix A). However, with respect to prosody, the items that contained a PB after V1 in Experiment 1 now contained both a PB after V1 and a pitch accent on NP2. The items that did not contain a PB after V1 were realized in the same way as in Experiment 1. The recording and cross-splicing procedures were the same as in Experiment 1, with one difference. The presence or absence of a pitch accent on NP2 might affect the prosody of NP1. Therefore, in Experiment 2, NP1 was not crossspliced separately, and thus, not the same token of NP1 was used in all four conditions of each item. In this way, we avoided a potentially unnatural prosody that might have occurred with the cross-splicing procedure used in Experiment 1.

Acoustic analyses were performed on the experimental sentences to compare the two prosodic conditions (see Appendix B, Table B2). NP1 had a somewhat longer duration (for both types of items) and a larger pitch range (only 
for subject-control items) in the sentences without a PB than in those with a PB. In contrast, the duration and the pitch range of NP2 were considerably larger in sentences with a PB and a pitch accent on NP2 than in sentences without these features. This held for both object- and subject-control items. Visual inspection revealed qualitative differences in the pitch track of V1 between the two prosodic conditions in both types of items. In sentences with a $\mathrm{PB}$, a more or less pronounced pitch rise occurred on V1 before the pause, whereas in sentences without a PB, a normal pitch accent or deaccentuation occurred on V1. For object- and subject-control items, a prefinal lengthening effect was found for the last stressed syllable and subsequent syllables of V1 and a pause was present between V1 and NP2 in sentences with a PB and pitch accent on NP2, but not in sentences without these features. All conditions contained a pause after V2. Figure B1 in Appendix B shows a sound waveform and pitch contour of two example sentences, one with a PB and pitch accent on NP2 and one without these features.

\section{Design, Procedure, and Apparatus}

The design, procedure, and apparatus were the same as in Experiment 1.

\section{Data Analysis for ERP Data}

Data analysis was the same as in Experiment 1, except for the late time window used to analyze the processing of the disambiguating verb (see below).

\section{Results}

\section{Sentence Recognition Task}

Out of the 28 participants, 21 correctly identified the sentence that they had heard out of the two presented sentences after all six experimental blocks. Seven participants made one error. Five of the errors were related to filler sentences and two were related to experimental sentences.

\section{ERPs to Prosodic Break}

For the analyses on the CPS, after artifact removal, a mean of 37 trials (range $=28-40$ trials, $S D=3.4$ ) per condition remained for object-control items, and a mean of 51 trials (range $=41-56$ trials, $S D=4.3$ ) for subject-control items, with no significant differences between conditions. Figure C1, Panel II in Appendix C presents grand-average waveforms at the midline electrodes, for the $\mathrm{PB}$ and no $\mathrm{PB}$ conditions of the object- and subject-control items time locked to the onset of the stressed syllable of V1 (just before the pause of the PB). Table C2 in Appendix C shows the relevant results from the statistical analyses of the CPS. Here, we only report the main conclusions of these analyses. Both object- and subject-control items showed a broadly distributed and robust CPS with a central maximum. Furthermore, a negativity preceding the CPS was found for the PB condition, both for the objectand subject-control items with a similar right-lateralized distribution.

\section{ERPs to Disambiguating Verb}

Figure 2 presents grand-average waveforms time locked to the onset of the disambiguating verb (V2) for all four conditions (for a subset of electrodes), separately for objectcontrol (A) and subject-control items (B). Visual inspection suggests an N400-like effect for intransitive relative to transitive V2s in Figure 2B (subject-control) at posterior electrodes. Figure 2B also shows a large difference between the two conditions with a PB and an accent on NP2 after $1000 \mathrm{msec}$. More specifically, a late positivity seems present for the intransitive as compared to the transitive V2 in sentences with a PB and an accent on NP2. We performed analyses for the standard N400 window (300-500 msec). For the late positivity, we chose an 1100-1400 msec window based on visual inspection of the grand-average waveforms and time-course analyses of $100 \mathrm{msec}$ windows.

Removal of artifacts before analyzing the N400 effect was based on an epoch from 150 msec before until $1000 \mathrm{msec}$ after V2 onset. A mean of 19 trials (range $=16-20$ trials, $S D=1.1$ ) per condition remained for object-control items and a mean of 27 trials (range $=22-28$ trials, $S D=1.3$ ) for subject-control items, with no significant differences between conditions. For the N400 effect in the object-control items, the midline analysis did not show any effects (all $p s>.20)$ and the lateral analysis yielded an interaction between Structure, Hemisphere, and ROI $[F(1,27)=$ $4.47, p<.05]$, but none of the single electrodes showed an N400 effect (all $p s>.07$ ). For the subject-control items, we found trends toward an interaction of Structure $\times$ Midline electrode in the midline analysis $[F(2,26)=2.90$, $p=.07]$, and toward an effect of Structure $[F(1,27)=3.98$, $p=.06]$ and a four-way $\mathrm{PB} \times$ Structure $\times$ Hemisphere $\times$ Electrode interaction $[F(3,25)=2.86, p=.06]$ in the lateral analysis. Follow-up analyses revealed no interactions between PB and Structure at the level of the single electrodes $(p s>.08)$, but five centro-parietal electrodes showed a larger $\mathrm{N} 400$ for the intransitive relative to the transitive conditions (P3, PO7, Pz, PO8, P8; ps < .05).

Thus, for the object-control items, no reliable differences between the conditions were found in the N400 time window. For the subject-control items, a small N400 effect for the intransitive relative to the transitive conditions was found with a standard centro-parietal distribution.

Before analyzing the late time window, artifacts were removed based on an epoch from $150 \mathrm{msec}$ before until $2000 \mathrm{msec}$ afterV2. A mean of 18 trials (range $=12-20$ trials, $S D=2.1$ ) per condition remained for object-control items and a mean of 26 trials (range $=17-28$ trials, $S D=2.6$ ) for subject-control items, without significant differences between conditions. For the object-control items, there were 
Figure 2. Grand-average waveforms time locked to the onset of the disambiguating verb (V2) in Experiment 2 (for a subset of electrodes), for the object-control items (A) and the subject-control items (B), for the four different conditions. In A (objectcontrol), no reliable effects are present. In B (subject-control), an N400 effect is present for both intransitive conditions relative to their corresponding transitive conditions and a later positivity is present in the 1100-1400 msec window only for the intransitive PB condition.
A Object-control
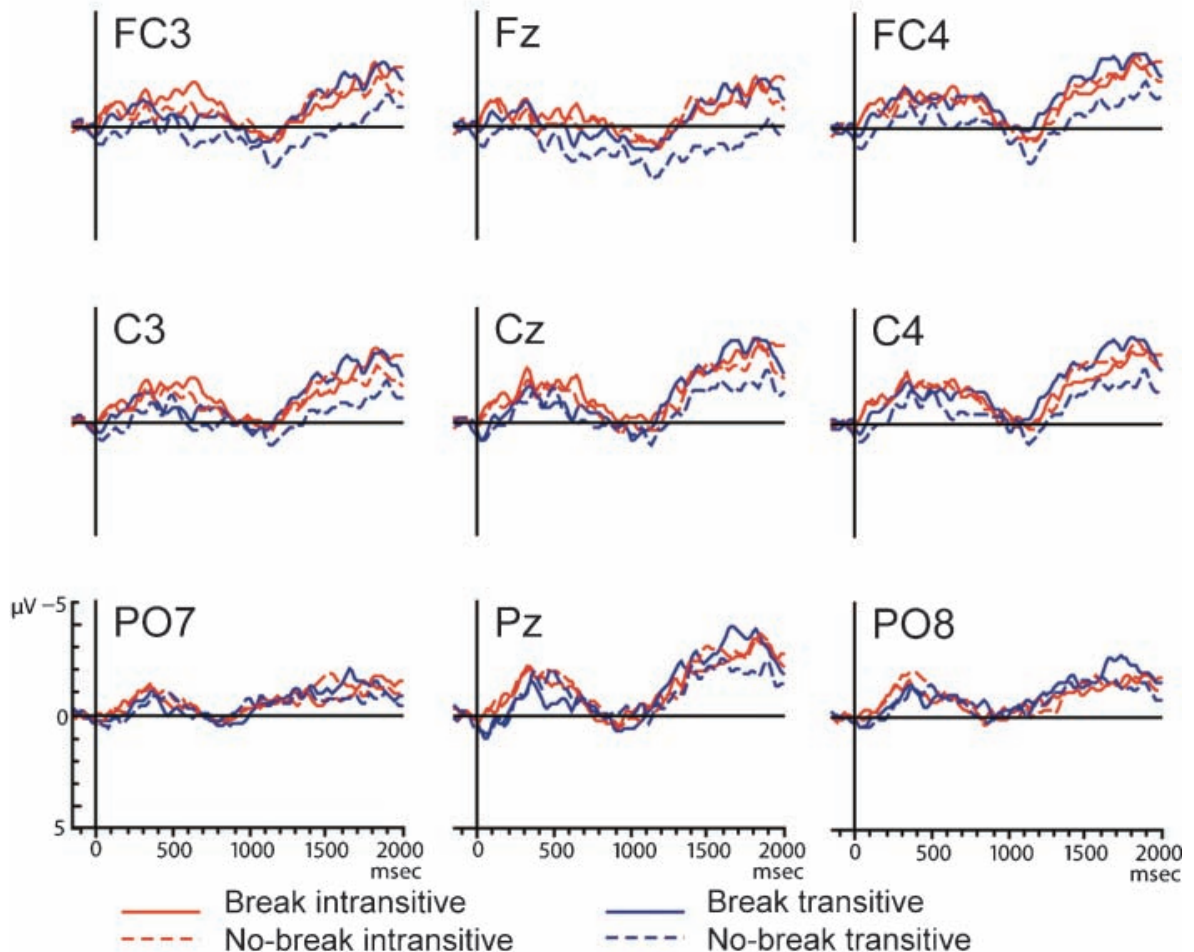

B Subject-control
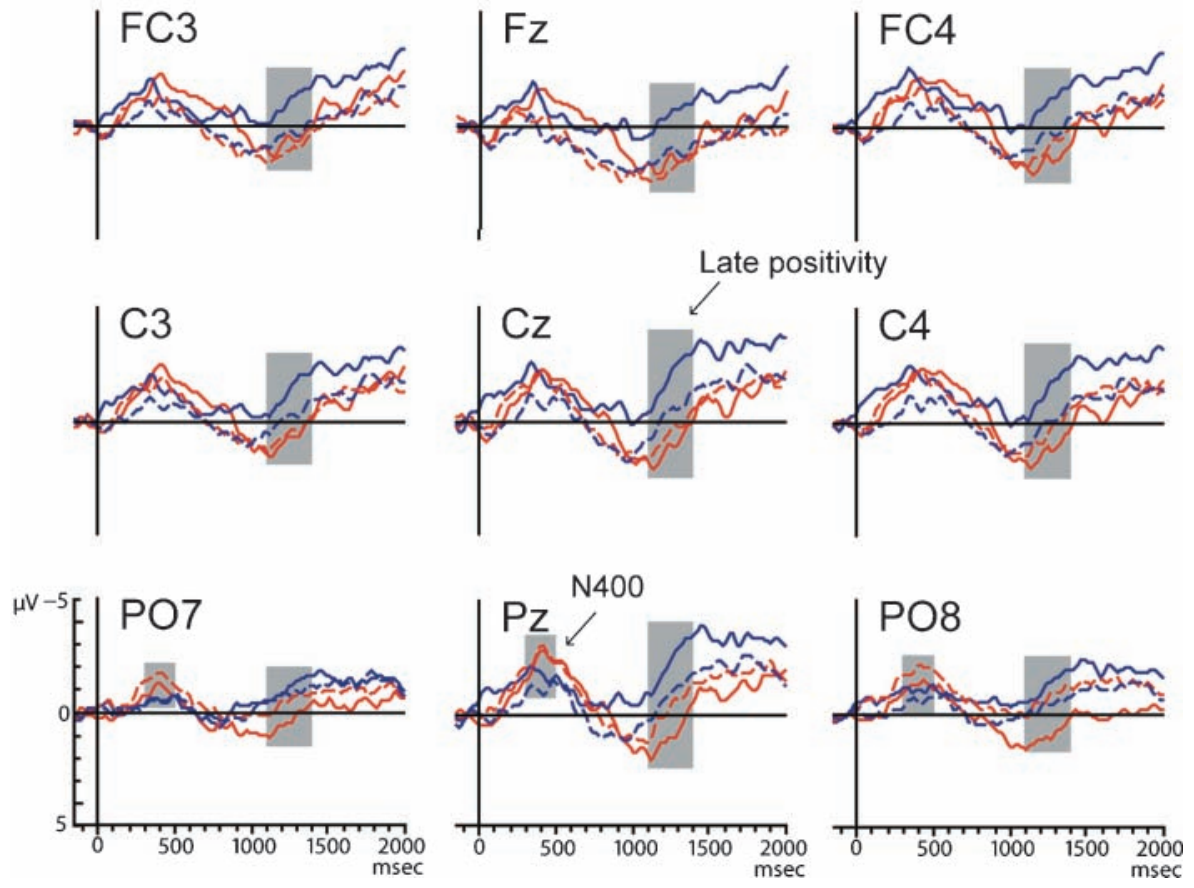

no significant differences in the 1100-1400 msec window $(p s>.12)$. In contrast, the analyses for the subject-control items for this window yielded a main effect of Structure $[F(1,27)=10.55, p<.01]$ and a Structure $\times$ PB interaction $[F(1,27)=7.15, p<.05]$ in the midline analysis. The lateral analysis yielded a main effect of Structure $[F(1,27)=10.10$, $p<.01]$ and an interaction between Structure and Electrode $[F(3,25)=3.07, p<.05]$. Furthermore, an interaction was found between structure and $\mathrm{PB}[F(1,27)=5.72, p<.05]$, as well as interactions of these two factors with Hemisphere $[F(1,27)=6.04, p<.05]$, with ROI $[F(1,27)=5.41, p<$ $.05]$, with Electrode $[F(3,25)=4.51, p<.05]$, and with 
ROI and Electrode $[F(3,25)=4.85, p<.01]$. Separate analyses for the no PB conditions did not show any effects of Structure (all $p s>$.16). In contrast, analyses for the PB conditions showed a main effect of Structure in the midline $[F(1,27)=24.91, p<.001]$ and lateral $[F(1,27)=17.03$, $p<.001]$ analyses as well as interactions between Structure and Electrode $[F(3,25)=8.22, p<.001]$ and between Structure, ROI, and Electrode $[F(3,25)=6.46, p<.01]$ in the lateral analysis. Follow-up analyses showed that this late positivity for the intransitive as compared to the transitive V2s in sentences with a PB and a pitch accent on NP2 was widely distributed across the scalp, but was maximal over the posterior region.

To summarize the results at the disambiguating verb for Experiment 2, for subject-control items, we found a small N400 effect for the intransitive as compared to the transitive V2, in both prosodic conditions. In addition, only for the sentences with a PB and an accent on NP2 was a late positivity obtained for the intransitive as compared to the transitive V2. For object-control items, no effects, neither in the N400 window nor in the late window, were observed.

\section{Discussion}

In Experiment 2, we introduced a pitch accent on NP2 in addition to the $\mathrm{PB}$ and compared this condition to one without these prosodic cues (no PB and no pitch accent on NP2). We again found a broadly distributed CPS in response to the PB, which was largest at the central electrodes. A small right-lateralized negativity preceded the CPS for both object- and subject-control items.

At the disambiguating verb of object-control items, no evidence for a reliable difference between the processing of intransitive and transitive V2s was found. For subjectcontrol items, Experiment 2 replicates the N400 effect at the disambiguating V2 found by Bögels et al. (2010) and in Experiment 1. Again, an intransitive V2 elicited a larger N400 than a transitive V2, and this was the case for sentences with a PB and without a PB. The N400 effect was present in the standard 300-500 msec window and showed the typical centro-posterior scalp distribution. However, in contrast to Experiment 1 (and Bögels et al.), the N400 was followed by a late positivity (time window: 1100-1400 msec) for the intransitive relative to the transitive disambiguating verb. This effect was only present for the subject-control items with a PB and a pitch accent on NP2, and was absent for the subject-control items without these two prosodic features. In the General Discussion, we will show how these results fit with our extrapolation of SAAR (Gussenhoven, 1999) proposed in the Introduction.

\section{GENERAL DISCUSSION}

The present study addressed the question whether two different prosodic devices, a prosodic break and a pitch ac- cent, can have a similar function, namely, to group words in a sentence together. A PB can have such a function as it can be taken as an indication of a syntactic break, and it is meanwhile well established that this is the case (e.g., Bögels et al., 2010; Kerkhofs et al., 2007; Steinhauer et al., 1999). For pitch accents, a similar function is less obvious, and has not yet been documented. However, as we argued in the Introduction, a pitch accent can introduce a broad-focus interpretation, such that an accented argument and an unaccented adjacent predicate are grouped together. Such a broad-focus interpretation, in turn, requires that the predicate and the argument can be integrated successfully, that is, that the predicate has an open slot for the (accented) argument. Before turning to a detailed discussion of the results concerning this question, we will briefly discuss the ERP effects at the PB.

\section{Effects at the PB}

Both experiments replicated an ERP effect elicited by the $\mathrm{PB}$, the closure positive shift (CPS; e.g., Bögels et al., 2010; Kerkhofs et al., 2007; Steinhauer et al., 1999). The CPS was broadly distributed, somewhat more rightlateralized in Experiment 1 and more central in Experiment 2 . The amplitude, timing, and distribution were similar for object- and subject-control items. The CPS was preceded by a negativity. In Experiment 1, this negativity was only significant for the object-control items. In Experiment 2, it was present for both types of items, but was restricted to the right hemisphere. Such a negativity preceding the CPS has been found in a number of previous studies (e.g., Pauker, Itzhak, Baum, \& Steinhauer, submitted; Kerkhofs et al., 2007; Pannekamp, Toepel, Alter, Hahne, \& Friederici, 2005), and Bögels et al. also found a right lateralization of the effect. The effect often starts early. In the present experiments, it started about $300 \mathrm{msec}$ before the average pause onset, suggesting that the negativity is elicited by prosodic markers preceding the pause, such as prefinal lengthening and boundary tone. The functional significance of this effect, however, still has to be established.

\section{Effects at the Disambiguation: Object-control Items}

In Experiment 1, we found an N400 effect for intransitive V2s relative to transitive V2s for sentences with a PB and without a PB. In Experiment 2, which introduced a pitch accent on NP2 in sentences with a PB, by contrast, no N400 effects were found. Both patterns differ from the results of Bögels et al. (2010), which showed an N400 effect for intransitive V2s only for sentences with a PB.

This variability in results suggests that listeners do not have a stable preference for a transitive or intransitive V2 in object-control items. However, a closer look at the results of Bögels et al. (2010) and the present experiments reveals the following systematic pattern for on-line processing of 
object-control items. In conditions without a $\mathrm{PB}$, we found either no difference between a transitive and an intransitive V2 (Bögels et al., and the present Experiment 2) or an N400 effect for an intransitive V2 (present Experiment 1), but we never obtained an N400 effect for transitive V2s. Thus, in online processing of object-control items, listeners appear to vary between "no preference" and a preference for transitive V2s, and they never show a preference for an intransitive V2. Several variables might have contributed to the preference we find for the specific items in the current study. We will regard these, in turn, to see whether they could have played a role. First, as discussed in the Introduction, the object-control items with a transitive and an intransitive V2 differ with respect to the presence of implicit arguments in the sentence. The items with an intransitive V2 do not contain any implicit arguments, because NP2 is both an indirect object of V1 and an understood subject of V2. In contrast, in the items with a transitive V2, the entity carrying these functions (indirect object of V1 and understood subject of V2) remains implicit. Because of this implicit entity, which might have to be filled in by listeners, one would expect the items with a transitive V2 to be more difficult to understand than those with an intransitive V2. However, if anything, the results indicate a larger N400 for the items with an intransitive V2. Second, parsing principles, such as minimal attachment and late closure (e.g., Pickering, Traxler, \& Crocker, 2000), would predict that NP2, as soon as it is encountered, is incorporated in the current clause and is thus interpreted as an (indirect) object of V1. This fits with a preference for an intransitive V2 (see, e.g., Steinhauer et al., 1999, who assumed, but did not show, such a default analysis for parallel constructions in German), which is opposite to the preference that we find. Third, we looked at the frequency distribution of constructions with control verbs in a corpus of spoken Dutch (Corpus Gesproken Nederlands). This corpus analysis shows that the objectcontrol verbs used in the present study took an explicit indirect object in $84 \%$ out of 215 sentences. On the basis of these frequency results, one would also expect a preference for an intransitive V2. This is again in opposition to the present results, but in accordance with the results of an off-line fragment completion test (Bögels et al., Experiment 1). Fourth, possible differences in, for instance, general complexity, cloze probability, and frequency between the transitive and intransitive verbs that were used in the current study, could have played a role. A transitive verb can be regarded as requiring a more complex integration than an intransitive verb because it has more argument slots, and therefore, would be expected to elicit a larger N400. Furthermore, both the cloze probability ( 0.12 for intransitive vs. 0 for transitive V2s) and the frequency (1739 for intransitive vs. 143 for transitive V2s, from the CELEX database; Baayen, Piepenbrock, \& Van Rijn, 1993) are larger for the intransitive than for the transitive verbs used, also pointing in the direction of a reduced $\mathrm{N} 400$ for intransitive verbs. In summary, none of the above factors (implicit arguments, parsing principles, frequency of constructions, transitive- intransitive verb differences) can explain the preference for a transitive V2 or no preference for either V2, as found for object-control items.

The most important comparison of the present study concerns items with a PB that do or do not contain a pitch accent on NP2. Object-control items with a PB and no pitch accent on NP2 consistently show a processing difficulty in the form of an $\mathrm{N} 400$ effect for intransitive as compared to transitive V2s (Bögels et al., 2010, and the present Experiment 1). This is in line with the fact that the PB (syntactically) separates V1 from NP2. However, Experiment 2 shows that this processing difficulty disappears when the sentences have a PB and a pitch accent on NP2. This pattern of results fits nicely with the considerations about pitch accents and broad-focus interpretation (see Introduction). The PB separates NP2 from V1, and thus, NP2 cannot be the indirect object of V1. On hearing an intransitive V2, however, this turns out to be syntactically incorrect as NP2 cannot be a (direct) object of this intransitive V2 (and thus, should be the indirect object of V1). But at the same time, the pitch accent on NP2 triggers a broad-focus analysis according to which NP2 should be an argument of V2. Because V1 is an object-control verb, NP2 is the understood subject of $\mathrm{V} 2$ and can thus, in terms of argument structure, be analyzed as an argument (subject) of V2. Thus, we have two competing forces: The PB initially leads to the syntactically incorrect analysis of NP2 not being the indirect object of V1, but the broad-focus interpretation induced by the pitch accent on NP2 triggers a strong tendency to analyze NP2 as an argument (the understood subject) of V2. The absence of any ERP effects at V2 suggests that, in this situation, speakers accept the interpretation resulting from the broad focus as "good enough" without paying attention to the incorrect syntactic analysis of NP2. Thus, for example, a sentence like "The surgeon advised // the WOMAN to sleep" would be interpreted as "The surgeon gave the advice that the woman should sleep." This relates to the idea of "good-enough representations" put forward by Ferreira, Bailey, and Ferraro (2002). They argue that in certain circumstances, listeners interpret, in particular, difficult sentences (such as passives) using a semantic heuristic rather than a syntactic algorithm. In these cases, listeners do not necessarily obtain the exact true meaning of the sentence, but arrive at a good-enough interpretation. It is conceivable that such a strategy was also used by the participants in the present Experiment 2, as the sentences are syntactically difficult. Moreover, participants did not perform an additional task, which would force them to analyze the sentences very thoroughly. Instead, they were asked to try to understand the sentences as they would do in daily life. Therefore, listeners might have used the pitch accent on NP2 to arrive at a coherent, and thus, "good-enough" interpretation of the argument structure of the sentence, without any specific processing difficulty. This clearly contrasts with sentences with a PB and no pitch accent on NP2 (Bögels et al. and present Experiment 1), which consistently showed processing difficulty at the intransitive V2. 
In summary, at the disambiguating verb of object-control items without explicit prosodic cues, we found an N400 effect for the intransitive disambiguating verb. This indicates a default preference for a transitive disambiguation, and thus, a preference for syntactically coupling the disambiguating verb to the previous noun. The same result was found when a PB was present before the noun, showing that grouping by a PB alone did not strengthen this effect. A stronger coupling between the noun and the disambiguating verb was found when, in addition to the PB, the noun carried a pitch accent. Because such a coupling was semantically possible for both the intransitive and the transitive disambiguating verb in object-control sentences, the N400 effect disappeared, showing that listeners accepted a "good-enough" interpretation of the sentence.

\section{Effects at the Disambiguation: Subject-control Items}

For the subject-control items, we found a general N400 effect for the intransitive relative to the transitive disambiguating verb. This effect was not modulated by the prosody of the sentence; it was found for sentences without PB and accent on NP2 (Experiments 1 and 2), for sentences with only a PB (Experiment 1), and for sentences with a PB and an accent on NP2 (Experiment 2). These results replicate those found by Bögels et al. (2010) and suggest that listeners have a reliable and strong preference for a transitive V2 in subject-control items, which is also in line with the results of an off-line fragment completion experiment (Experiment 1 of Bögels et al.). We will first consider whether the variables discussed above for object-control items can account for the reliable preference found for subject-control items. First, parsing principles, such as minimal attachment and late closure, as explained above, point to the opposite direction. Second, when we searched in a corpus of spoken Dutch (Corpus Gesproken Nederlands) for the subject-control verbs that we used in the present study, we found that in $94 \%$ of 154 sentences, the subjectcontrol verb did not have an overt indirect object. If a subject-control verb almost never takes an explicit indirect object, listeners would not expect an NP following a subject-control verb to fulfill this function. A transitive $\mathrm{V} 2$ fits best with this expectation because NP2 is free to become direct object of V2. Thus, in the case of subject-control verbs, frequency of the construction is a possible explanation for the present ERP results. However, because this was not the case for object-control verbs, this factor cannot give a general explanation for the pattern of results in both subject- and object-control verbs. Third, regarding differences between transitive and intransitive verbs, again, transitive verbs can be regarded as more complex (leading to a larger N400) than intransitive verbs. The cloze probability of the specific V2s used in the present materials did not differ between the two types of verbs in subject-control items (both .02), and the frequency was again larger for the intransitive than for the transitive verbs (1177 vs. 416, respectively in the CELEX database; Baayen et al., 1993), which suggests a reduced $\mathrm{N} 400$ for intransitive verbs. In summary, none of the considered factors (parsing principles, frequency of constructions, transitive-intransitive verb differences) can account for the preference for a transitive verb in both types of control sentences. Future research will have to show which factors are responsible for this preference.

Again, as for the object-control items, the most important comparison for the subject-control items concerns the items with a PB that do or do not contain a pitch accent on NP2. Subject-control items with a PB consistently show an $\mathrm{N} 400$ effect at the intransitive as compared to the transitive V2 (Bögels et al., 2010 and the current Experiment 1). However, Experiment 2 shows that sentences with a PB and a pitch accent on NP2 do not only show this N400 effect, but in addition, yield a large and broadly distributed positivity for intransitive V2s that was maximal over posterior sites. This late positivity thus appears to be elicited by the combination of a PB and a pitch accent on NP2. An accent on NP2 can introduce a broad focus, that is, a focus not only on NP2 but also on NP2 and an adjacent verb, such as V2. Such a broad focus requires that NP2 can be an argument of V2. However, in the case of a subject-control V1 and an intransitive V2, NP2 cannot be an argument of V2, as NP1 is the understood subject of V2, and V2 is intransitive, excluding the option that NP2 is an object of V2. The resulting processing difficulty appears to be reflected in the late positivity.

An important language-related ERP component is the $\mathrm{P} 600$. This positivity is generally found as a signature of a syntactic revision, around 600 to $800 \mathrm{msec}$. In our case, the positivity occurs much later, around 1100 to $1400 \mathrm{msec}$. However, earlier studies already found variability in the latency of the $\mathrm{P} 600$, especially in relation to prosodic mismatches (e.g., Astésano, Besson, \& Alter, 2004). This is also the case in a study that is very similar to the present study. Steinhauer et al. (1999) studied the processing of locally ambiguous German sentences with the same structure as the Dutch sentences of the present study. In the present context, the most important two conditions of their study are those items with a PB after V1 and a major accent on NP2 (p. 195). These items were disambiguated by a transitive or an intransitive verb. The study by Steinhauer et al. also used object- and subject-control verbs as V1, but the data were collapsed across these two types of verbs. Steinhauer et al. found an N400 effect followed by a late positivity for the intransitive relative to the transitive disambiguating verb. The positivity was significant between 1200 and $1800 \mathrm{msec}$ after the onset of the disambiguating verb, that is, in a similarly late time window as the positivity in the present Experiment 2. Steinhauer et al. refer to this positivity as a P600 effect and assume that it indicates a syntactic and prosodic revision. Although Steinhauer et al. do not discuss the late timing of the $\mathrm{P} 600$ effect, it is possible that prosodic revision, because it might involve subvocal corrections (p. 195), takes longer than syntactic revision. Although the present Experiment 2 is very similar to the study of Steinhauer et al., the results are difficult to compare because Steinhauer et al. 
collapsed over object- and subject-control items. When collapsing the data of the present Experiment 2 over these two types of items, we obtain a similar pattern as Steinhauer et al., namely, a biphasic N400-P600 pattern for an intransitive $\mathrm{V} 2$ relative to a transitive $\mathrm{V} 2$ in sentences with a $\mathrm{PB}$ and a pitch accent on NP2. However, the pattern of results that we found by taking into account the (semantic) differences between the two types of items shows that the late positivity is only carried by subject-control items with an intransitive V2. This is completely in line with the idea that the pitch accent on NP2 leads listeners to consider NP2 as a potential argument of V2 (which is impossible for an intransitive V2 in subject-control items).

Assuming that the late positivity indeed can be regarded as a $\mathrm{P} 600$, we can relate the present results to the Monitoring Theory of the P600 (e.g., Vissers, Kolk, Van de Meerendonk, \& Chwilla, 2008). This theory states that a $\mathrm{P} 600$ will be elicited in the case of a strong conflict between an "expected" and an actually encountered representation. In the present study, a pitch accent on NP2 triggers a broad-focus interpretation and might thereby elicit an expectation for an adjacent verb that can take NP2 as its argument. Because the $\mathrm{PB}$ precludes the preceding verb as taking that function, the following word would then be expected to be a verb with this property, that is, a transitive verb. The P600 effect would then reflect the violation of this expectation. Alternatively, following a proposal put forward by Bornkessel and Schlesewsky (2006), the late positivity could be considered as reflecting a problem with generalized mapping, where several sources of information (such as prosodic pitch information and information about linking arguments to predicates) are brought together. In this case, these information sources cannot be integrated properly, thus the late positivity may reflect repair processes.

In summary, subject-control items with and without a PB yielded an N400 effect at the intransitive relative to the transitive disambiguating verb. This result points to a default preference for a transitive disambiguation that is not strengthened by the grouping created by a PB alone. However, when a pitch accent was added on a preceding noun, this led to a combined N400 and P600 effect for the intransitive disambiguation. This shows that the disambiguating verb and the accented noun were grouped together in a broad-focus domain created by the pitch accent. This grouping was both syntactically and semantically impossible for subject-control sentences with an intransitive disambiguating verb, leading to a strong processing difficulty.

\section{Conclusion}

Both prosodic phrasing and accentuation can group words, the former on the syntactic level and the latter on the level of information structure. When the grouping of words suggested by accentuation leads to a coherent semantic representation, this can lead listeners to pursue a "good-enough" semantic interpretation, while ignoring syntactic cues induced by prosodic phrasing. Conversely, the grouping of words by accentuation can lead to serious processing problems when it clashes with syntactic cues and does not allow for a coherent (good enough) semantic interpretation.

\section{APPENDIX A: EXPERIMENTAL SENTENCES}

Sentences with an intransitive V2 are always given first and sentences with a transitive V2 are given second. Items with the same control verb (V1) are placed after each other. Some items were changed in Experiment 2 relative to Experiment 1. In these cases, the item that was used in Experiment 2 is added under the same number, followed by Exp. 2 in brackets object-control items or subject-control items.

\section{Object-control Items}

1. De huisarts adviseerde de vrouw te sporten om wat gewicht te verliezen.

2. De huisarts adviseerde de vrouw te motiveren om wat gewicht te verliezen.

3. De chirurg adviseerde de vrouw te slapen voordat ze onder het mes zou moeten.

4. De chirurg adviseerde de vrouw te ondersteunen voordat ze onder het mes zou moeten.

5. De commandant beval de soldaat te vuren en het lijk op te ruimen.

6. De commandant beval de soldaat te vermoorden en het lijk op te ruimen.

7. De commissaris beval de agent te spioneren om meer van de zaak te weten te komen.

8. De commissaris beval de agent te bespioneren om meer van de zaak te weten te komen.

9. De koning gebood de schildknaap te knielen waarna hij hem tot ridder sloeg.

10. De koning gebood de schildknaap te belonen waarna hij hem tot ridder sloeg.

11. De hertogin gebood de chauffeur te claxonneren omdat er zich een noodgeval had voorgedaan.

12. De hertogin gebood de chauffeur te verwittigen omdat er zich een noodgeval had voorgedaan.

13. De minister gelastte de toehoorder te vertrekken van de publieke tribune.

14. De minister gelastte de toehoorder te verwijderen van de publieke tribune.

15. De rechter gelast de aanwezigen te zwijgen omdat ze anders de rechtsgang beletten.

16. De rechter gelast de aanwezigen te verwijderen omdat ze anders de rechtsgang beletten. 
17. De verpleegster hielp de zieke te lopen zodat de familie niet langer hoefde te wachten.

18. De verpleegster hielp de zieke te vervoeren zodat de familie niet langer hoefde te wachten.

19. De bewaker hielp de moordenaar te ontsnappen uit de beruchte gevangenis.

20. De bewaker hielp de moordenaar te bevrijden uit de beruchte gevangenis.

21. De bankmedewerker ontraadde de manager te beleggen en wees op de negatieve gevolgen.

22. De bankmedewerker ontraadde de manager te benadelen en wees op de negatieve gevolgen.

23. De chirurg ontraadde de patiënte te ontbijten zodat ze zich kon voorbereiden op de ingreep.

24. De chirurg ontraadde de patiënte te vermoeien zodat ze zich kon voorbereiden op de ingreep.

25. De actrice smeekte de regisseur te volharden omdat ze heimelijk verliefd op hem was.

26. De actrice smeekte de regisseur te behouden omdat ze heimelijk verliefd op hem was.

27. De fan smeekte de zanger te komen om op het feest te zingen.

28. De fan smeekte de zanger te boeken om op het feest te zingen.

De fan smeekte de zanger te verzoeken om op het feest te zingen. (Exp. 2)

29. De dictator verbood de burger te liegen en gaf verdere orders aan de bewakers.

30. De dictator verbood de burger te pijnigen en gaf verdere orders aan de bewakers.

31. Het schoolhoofd verbood de kinderen te praten en ging verder met zijn ronde langs de klassen.

32. Het schoolhoofd verbood de kinderen te verontrusten en ging verder met zijn ronde langs de klassen.

33. De directeur verplicht de arbeiders te pauzeren als ze te veel fouten maken.

34. De directeur verplicht de arbeiders te ontslaan als ze te veel fouten maken.

35. De arts verplicht de zieken te rusten voordat ze een grote ingreep ondergaan.

36. De arts verplicht de zieken te ontsmetten voordat ze een grote ingreep ondergaan.

37. De chef verzocht de werknemer te vertrekken omdat het slecht ging met het bedrijf.

38. De chef verzocht de werknemer te ontslaan omdat het slecht ging met het bedrijf.

39. De brandweerman verzoekt de omstanders te wijken om de brandweerauto doorgang te geven.

40. De brandweerman verzoekt de omstanders te verwijderen om de brandweerauto doorgang te geven.

\section{Subject-control Items}

41. De wetenschapper antwoordt de interviewer te zullen triomferen als hij weer een nieuwe ontdekking heeft gedaan.

42. De wetenschapper antwoordt de interviewer te zullen inlichten als hij weer een nieuwe ontdekking heeft gedaan.

43. De secretaresse antwoordde de conciërge te zullen komen om het probleem op te lossen.

44. De secretaresse antwoordde de conciërge te zullen vragen om het probleem op te lossen.

De secretaresse antwoordde de conciërge te zullen halen om het probleem op te lossen. (Exp. 2)

45. De leerling bekende de leraar te hebben gespiekt tijdens het eerste uur.

46. De leerling bekende de leraar te hebben opgesloten tijdens het eerste uur.

47. De automobilist bekende de agent te hebben gereden met te veel drank op.

De man bekende de agent te hebben gefietst met te veel drank op. (Exp. 2)

48. De automobilist bekende de agent te hebben aangereden met te veel drank op.

De man bekende de agent te hebben aangereden met te veel drank op. (Exp. 2)

49. De voetballer belooft de trainer te zullen excelleren en de beker te winnen.

50. De voetballer belooft de trainer te zullen verblijden en de beker te winnen.

51. De vrouw beloofde de stervende te zullen rouwen en hem eerbiedig te zullen gedenken.

52. De vrouw beloofde de stervende te zullen begraven en hem eerbiedig te zullen gedenken.

53. De generaal bericht de koning te zullen capituleren en te zullen terugkeren naar het vaderland.

54. De generaal bericht de koning te zullen ondersteunen en te zullen terugkeren naar het vaderland.

55. De voorzitter bericht de leden te zullen vertrekken maar niet zonder een daverend afscheidsfeest.

56. De voorzitter bericht de leden te zullen verlaten maar niet zonder een daverend afscheidsfeest.

57. De crimineel bezweert de handlanger te zullen zwijgen en niet zomaar de gevangenis in te gaan.

58. De crimineel bezweert de handlanger te zullen verraden en niet zomaar de gevangenis in te gaan.

59. De minister bezweert de staatssecretaris te zullen strijden om de verkiezingen te kunnen winnen.

60. De minister bezweert de staatssecretaris te zullen benadelen om de verkiezingen te kunnen winnen.

61. De dokter garandeerde de patiënt te zullen zwijgen en de familie niets te vertellen.

62. De dokter garandeerde de patiënt te zullen beschermen en de familie niets te vertellen. 
63. De rector garandeerde de lerares te zullen standhouden tegenover de boze ouders.

64. De rector garandeerde de lerares te zullen verdedigen tegenover de boze ouders.

65. De verdachte getuigt de agent te hebben geslapen en dus onschuldig te zijn aan de misdaad.

66. De verdachte getuigt de agent te hebben beschermd en dus onschuldig te zijn aan de misdaad.

67. De gedaagde getuigt de rechter te hebben gelogen omdat hij onder druk werd gezet.

De gedaagde getuigt de rechter te hebben gelogen waar hij nu veel spijt van heeft. (Exp. 2)

68. De gedaagde getuigt de rechter te hebben beledigd omdat hij onder druk werd gezet.

De gedaagde getuigt de rechter te hebben bespot waar hij nu veel spijt van heeft. (Exp. 2)

69. De getuige verklaarde de rechter te zullen praten en negeerde vervolgens de vele journalisten.

70. De getuige verklaarde de rechter te zullen verrassen en negeerde vervolgens de vele journalisten.

De getuige verklaarde de rechter te zullen inlichten en negeerde vervolgens de vele journalisten.

71. De minister verklaart de asielzoekers te zullen onderhandelen zodat ze in Nederland kunnen blijven.

72. De minister verklaart de asielzoekers te zullen naturaliseren zodat ze in Nederland kunnen blijven.

73. De tennisser vertelde de trainer te hebben gefaald en daar absoluut niet trots op te zijn.

74. De tennisser vertelde de trainer te hebben geraakt en daar absoluut niet trots op te zijn.

75. De wielrenner vertelde de journalisten te willen rusten omdat hij erg moe was.

76. De wielrenner vertelde de journalisten te willen ontlopen omdat hij erg moe was.

77. De vrouw verzekerde de zieke te zullen overnachten zodat hij niet helemaal alleen zou zijn.

78. De vrouw verzekerde de zieke te zullen bezoeken zodat hij niet helemaal alleen zou zijn.

79. De studente verzekerde de docent te zullen feesten als ze haar tentamen zou halen.

80. De studente verzekerde de docent te zullen bedanken als ze haar tentamen zou halen.

De studente verzekerde de docent te zullen omhelzen als ze haar tentamen zou halen. (Exp. 2)

81. Het kind vraagt de oppas te mogen winkelen in de grote stad.

82. Het kind vraagt de oppas te mogen bezoeken in de grote stad.
83. De prinses vraagt de kroonprins te mogen zingen zodat zij hem het hof kan maken.

84. De prinses vraagt de kroonprins te mogen inviteren zodat zij hem het hof kan maken.

De prinses vraagt de kroonprins te mogen uitnodigen zodat zij hem het hof kan maken.

85. De bewoonster waarschuwde de inbreker te zullen schreeuwen als hij dichterbij zou komen.

86. De bewoonster waarschuwde de inbreker te zullen aanvliegen als hij dichterbij zou komen.

87. De advocaat waarschuwde de officier te zullen gaan dwarsliggen omdat hij de zaak niet zomaar verloren wilde laten gaan.

De advocaat waarschuwde de officier te zullen strijden omdat hij de zaak niet zomaar verloren wilde laten gaan. (Exp. 2)

88. De advocaat waarschuwde de officier te zullen gaan dwarsbomen omdat hij de zaak niet zomaar verloren wilde laten gaan.

De advocaat waarschuwde de officier te zullen dwarsbomen omdat hij de zaak niet zomaar verloren wilde laten gaan. (Exp. 2)

89. De hooligan zei de agent te hebben gescholden omdat hij zijn agressie kwijt moest.

90. De hooligan zei de agent te hebben uitgescholden omdat hij zijn agressie kwijt moest.

91. De bezoeker zei de clown te hebben gelachen om zijn grappen en rare fratsen.

92. De bezoeker zei de clown te hebben gewaardeerd om zijn grappen en rare fratsen.

93. De studente zweert de professor te zullen blokken om het tentamen te halen.

De studente zweert de professor te zullen zwoegen om het tentamen te halen. (Exp. 2)

94. De studente zweert de professor te zullen omkopen om het tentamen te halen.

95. De heks zweert de dwergen te zullen lachen, als zij de laatste slag gewonnen heeft.

96. De heks zweert de dwergen te zullen uitlachen, als zij de laatste slag gewonnen heeft.

\section{APPENDIX B: ACOUSTIC ANALYSES}

Tables B1 and B2 present the measurements and statistical analyses of the acoustic analyses of Experiments 1 and 2, respectively. We measured the length of NP1 (NP1 length), NP2 (NP2 length), the unstressed syllables (if present) preceding the stressed syllable of V1 (V1 unstressed before), the stressed syllable of V1 (V1 stressed), the unstressed syllables (if present) following the stressed syllable of V1 
(V1 unstressed after), the pause of the PB following V1 in the PB conditions (Pause1 length), and the pause of the PB following V2 that was present in all conditions (Pause2 length). Furthermore, we measured the pitch range of NP1 (NP1 pitch range) and NP2 (NP2 pitch range).

Table B1. Means, SDs, Difference Values, and Significance for the Acoustic Analyses of the Experimental Materials of Experiment 1, Separately for the Object- and Subject-control Items

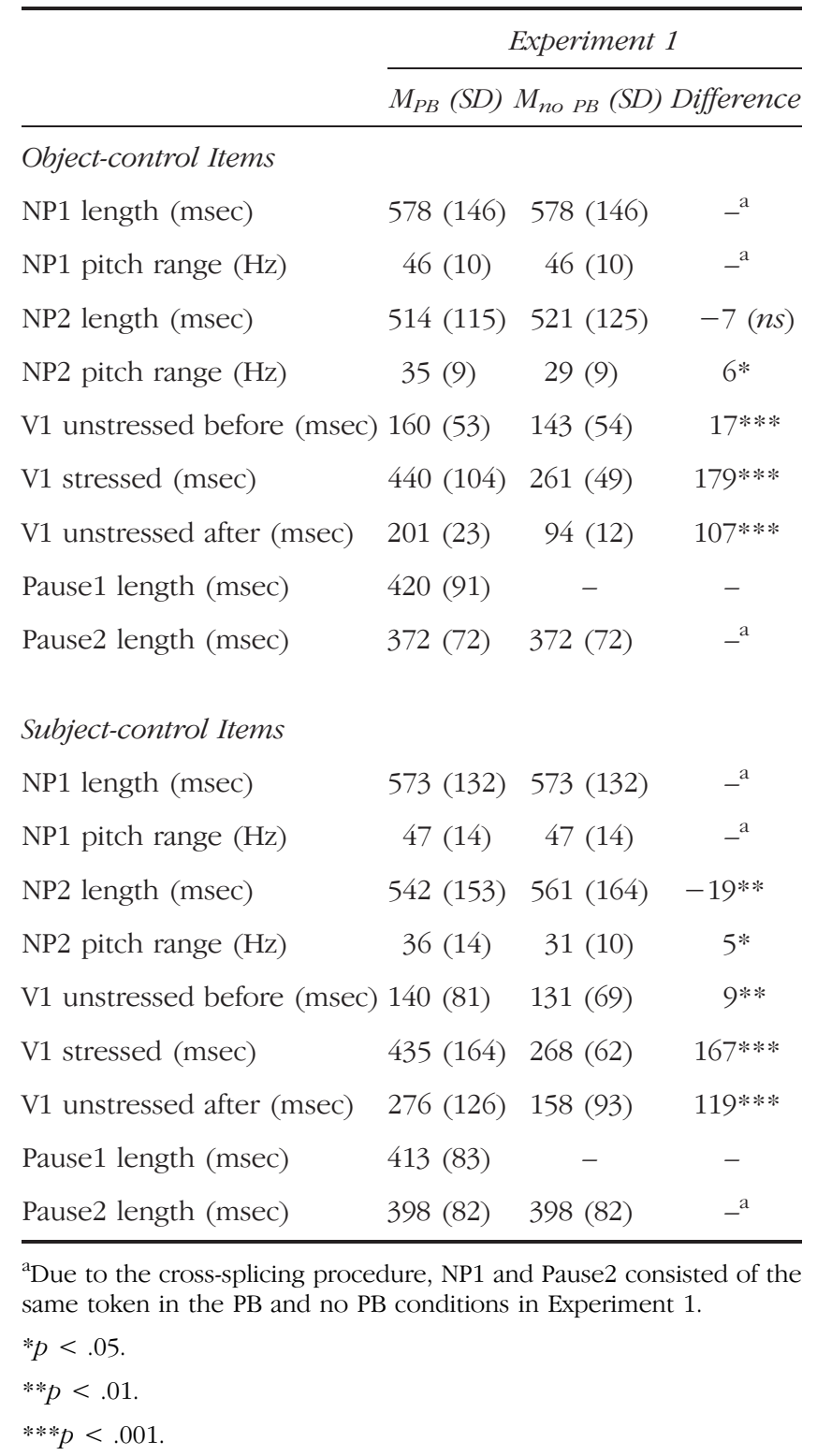

Figure B1 presents sound waveforms and pitch tracks for two example sentences of Experiment 2, providing qualitative information about the prosody in the condition with PB and pitch accent on NP2 and the condition without these features.

Table B2. Means, $S D$ s, Difference Values, and Significance for the Acoustic Analyses of the Experimental Materials of Experiment 2, Separately for the Object- and Subject-control Items

\begin{tabular}{|c|c|c|c|}
\hline & \multicolumn{3}{|c|}{ Experiment 2} \\
\hline & $M_{P B}(S D)$ & $M_{\text {no } P B}(S D)$ & Difference \\
\hline \multicolumn{4}{|l|}{ Object-control Items } \\
\hline NP1 length (msec) & $528(130)$ & $552(136)$ & $-24 * * *$ \\
\hline NP1 pitch range (Hz) & $63(23)$ & $72(20)$ & $-9(n s)$ \\
\hline NP2 length (msec) & $515(97)$ & $477(100)$ & $38 * * *$ \\
\hline NP2 pitch range $(\mathrm{Hz})$ & $104(36)$ & $42(16)$ & $62 * * *$ \\
\hline V1 unstressed before (msec) & $150(57)$ & $139(52)$ & $11^{*}$ \\
\hline V1 stressed (msec) & 377 (89) & $231(41)$ & $146 * * *$ \\
\hline V1 unstressed after (msec) & $185(23)$ & $75(11)$ & $110 * * *$ \\
\hline Pause1 length (msec) & 287 (95) & - & - \\
\hline Pause2 length (msec) & 321 & 321 & $-{ }^{\mathrm{a}}$ \\
\hline \multicolumn{4}{|l|}{ Subject-control Items } \\
\hline NP1 length (msec) & $499(97)$ & $511(102)$ & $-12 * * *$ \\
\hline NP1 pitch range (Hz) & $66(24)$ & 78 (19) & $-12 *$ \\
\hline NP2 length (msec) & $536(125)$ & $501(126)$ & $35 * * *$ \\
\hline NP2 pitch range (Hz) & $112(26)$ & $49(21)$ & $63 * * *$ \\
\hline V1 unstressed before (msec) & $153(73)$ & $147(64)$ & $6(n s)$ \\
\hline V1 stressed (msec) & $372(122)$ & $234(59)$ & $138 * * *$ \\
\hline V1 unstressed after (msec) & $184(58)$ & $104(62)$ & $79 * * *$ \\
\hline Pause1 length (msec) & 277 (106) & - & - \\
\hline Pause2 length (msec) & 316 & 316 & $-{ }^{\mathrm{a}}$ \\
\hline \multicolumn{4}{|c|}{$\begin{array}{l}{ }^{2} \text { Due to the cross-splicing procedure, Pause } 2 \text { consisted of the same token } \\
\text { in the } \mathrm{PB} \text { and no } \mathrm{PB} \text { conditions in Experiment } 2 .\end{array}$} \\
\hline \multicolumn{4}{|l|}{$* p<.05$} \\
\hline \multicolumn{4}{|l|}{$* * p<.01$} \\
\hline$* * * p<.001$. & & & \\
\hline
\end{tabular}


Figure B1. Sound waveforms and pitch tracks for two example sentences from Experiment 2. Panel A shows the no PB and no accent on NP2 condition with an intransitive V2 and Panel B shows the condition with both a PB and a pitch accent on NP2 with a transitive V2.

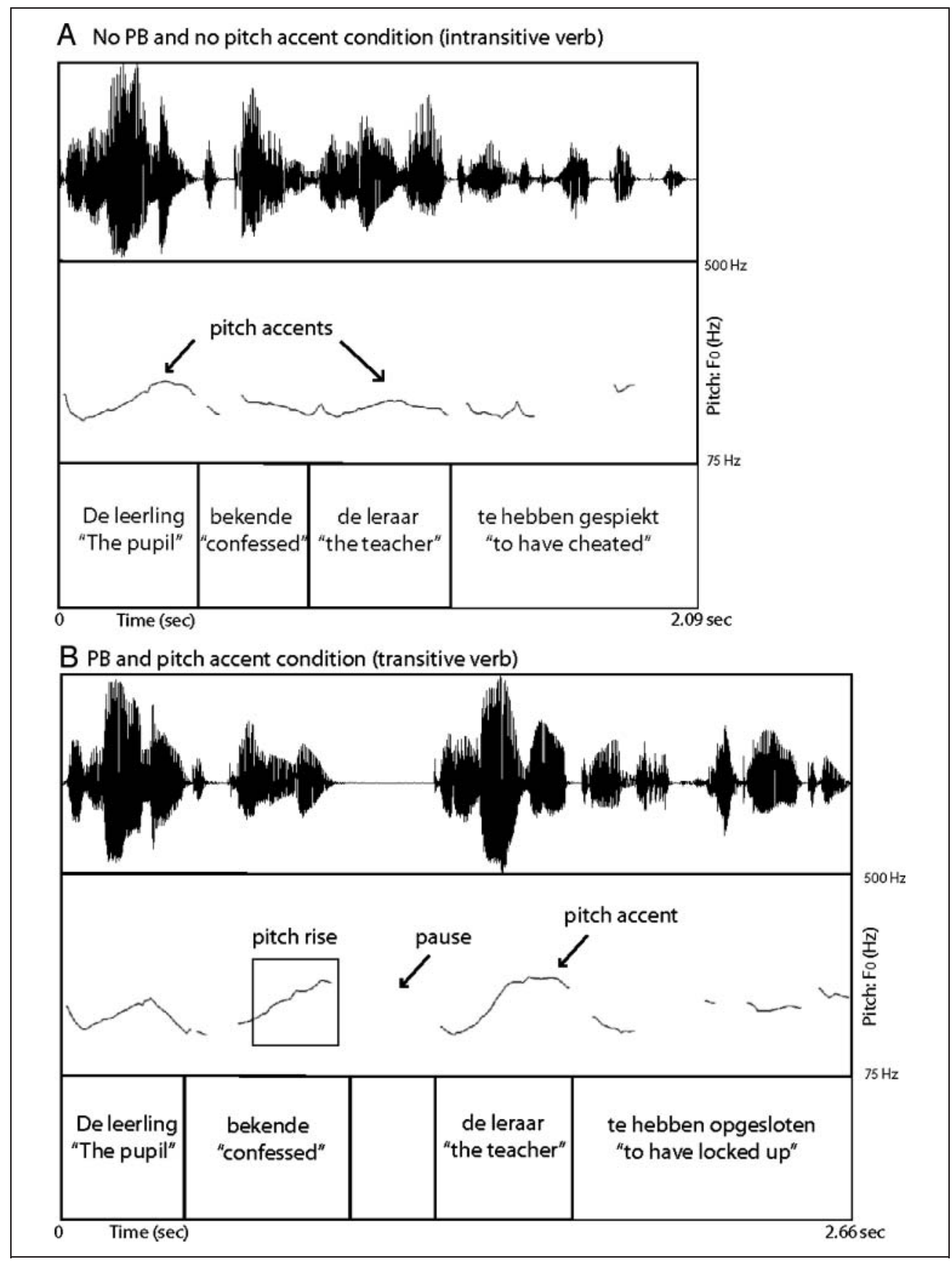




\section{APPENDIX C: GRAND AVERAGES AND ANALYSES OF THE CPS}

Figure $\mathrm{C} 1$ presents grand-average waveforms for the midline electrodes for the PB and no PB conditions of the object- and subject-control items time locked to the onset of the stressed syllable of V1 for Experiment 1 (Panel I) and Experiment 2 (Panel II). We collapsed the data over the two levels of structure (intransitive and transitive) for this time-locking point because the sentences in these two conditions did not differ up to the disambiguating region (i.e., V2).
A large CPS with a broad scalp distribution was present for both types of items and in both experiments. Furthermore, a smaller negativity seemed to be present preceding the CPS in some conditions. We chose a 300-500 msec window on the basis of visual inspection to investigate this effect (Bögels et al., 2010). Tables C1 and C2 show the results of the analyses of the CPS and the preceding negativity in Experiment 1 and Experiment 2, respectively. Figures containing all electrodes and a detailed report of the CPS analyses can be obtained from the corresponding author.

Table C1. Results of the Analyses of the CPS and Early Negativity in Experiment 1

\begin{tabular}{|c|c|c|c|c|}
\hline \multirow[b]{2}{*}{ Experiment 1} & \multicolumn{2}{|c|}{ Object-control Items } & \multicolumn{2}{|c|}{ Subject-control Items } \\
\hline & Negativity (300-500 msec) & CPS (800-1200 msec) & Negativity (300-500 msec) & CPS (800-1200 msec) \\
\hline PB (midline) & $F(1,27)=7.61^{*}$ & $F(1,27)=14.27 * *$ & & $F(1,27)=28.82 * *$ \\
\hline PB $\times$ Midline electrode & & & & $F(2,26)=7.77 * * *$ \\
\hline PB (lateral) & $F(1,27)=9.67 * * *$ & $F(1,27)=11.28 * * *$ & & $F(1,27)=19.14 * *$ \\
\hline $\mathrm{PB} \times$ Hemisphere & & $F(1,27)=6.15^{*}$ & & \\
\hline $\mathrm{PB} \times$ ROI $\times$ Electrode & $F(3,25)=6.29 * * *$ & $F(3,25)=3.27 *$ & & $F(3,25)=5.89 * * *$ \\
\hline $\mathrm{PB} \times$ Electrode & & $F(3,25)=6.34 * * *$ & & $F(3,25)=11.37 * *$ \\
\hline
\end{tabular}

Nonsignificant $F$ values are not reported.

$* p<.05$.

$* * p<.001$.

$* * * p<.01$

Table C2. Results of the Analyses of the CPS and Early Negativity in Experiment 2

\begin{tabular}{|c|c|c|c|c|}
\hline \multirow[b]{2}{*}{ Experiment 2} & \multicolumn{2}{|c|}{ Object-control Items } & \multicolumn{2}{|c|}{ Subject-control Items } \\
\hline & Negativity (300-500 msec) & CPS (800-1200 msec) & Negativity (300-500 $\mathrm{msec}$ & ) CPS (800-1200 msec) \\
\hline PB (midline) & & $F(1,27)=14.01 * * *$ & & $F(1,27)=7.53^{*}$ \\
\hline \multicolumn{5}{|l|}{ PB $\times$ Midline electrode } \\
\hline PB (lateral) & & $F(1,27)=10.58^{* *}$ & & $F(1,27)=11.15^{* *}$ \\
\hline $\mathrm{PB} \times$ Hemisphere & & & $F(1,27)=6.92 *$ & \\
\hline $\mathrm{PB} \times$ Hemisphere $\times$ Electrode & & & $F(3,25)=5.62 * *$ & $F(3,25)=3.02 *$ \\
\hline $\mathrm{PB} \times$ ROI $\times$ Electrode & $F(3,25)=2.51^{\dagger}$ & & $F(3,25)=3.44^{*}$ & $F(3,25)=4.37^{*}$ \\
\hline $\mathrm{PB} \times$ Electrode & & $F(3,25)=8.32 * * *$ & & $F(3,25)=5.84 * *$ \\
\hline PB (right hemisphere) & & & $F(1,27)=6.56^{*}$ & \\
\hline \multicolumn{5}{|c|}{ Nonsignificant $F$ values are not reported. } \\
\hline \multicolumn{5}{|c|}{$* p<.05$} \\
\hline \multicolumn{5}{|l|}{$* * p<.01$} \\
\hline$* * * p<.001$ & & & & \\
\hline${ }^{\dagger} p=.08$ & & & & \\
\hline
\end{tabular}


Figure C1. Grand-average waveforms for the midline electrodes for the $\mathrm{PB}$ and no $\mathrm{PB}$ conditions, time locked to the onset of the stressed syllable of the control verb (V1) in Experiment 1 (I) and in Experiment 2 (II), for object- and subject-control items. A CPS is present for the $\mathrm{PB}$ conditions relative to the no $\mathrm{PB}$ conditions in the 800-1200 msec window. In addition, a small negativity preceding the CPS is also present in some conditions, analyzed using a 300-500 msec window.

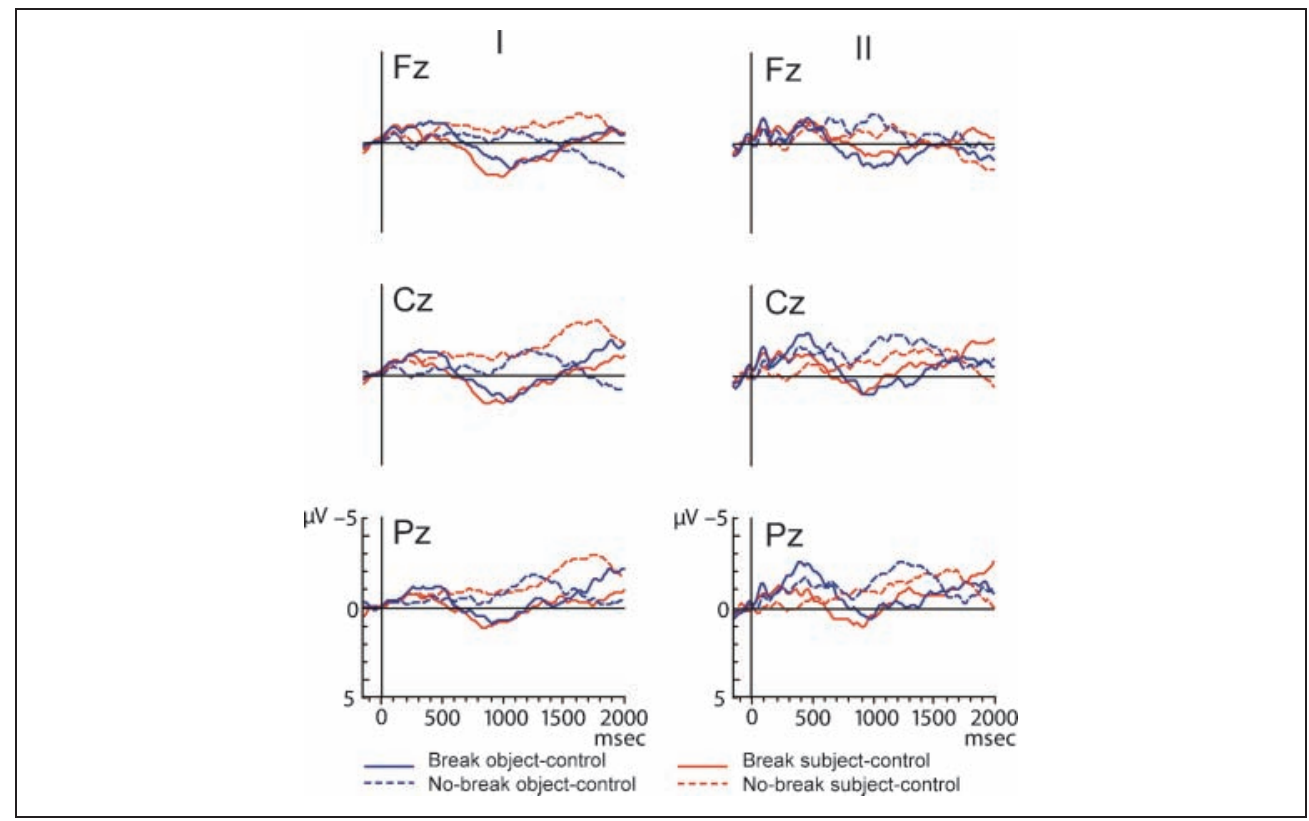

Reprint requests should be sent to Sara Bögels, Radboud University Nijmegen, P.O. Box 9104, 6500 HE Nijmegen, the Netherlands, or via e-mail: s.bogels@donders.ru.nl.

\section{Note}

1. In Dutch (and English), a few control verbs exist that can be ambiguous between a subject- and an object-control verb. However, in the present experimental sentences, the control verbs were always used in such a way that they were unambiguously interpreted as either subject- or object-control.

\section{REFERENCES}

Anderson, J. E., \& Holcomb, P. J. (1995). Auditory and visual semantic priming using different stimulus onset asynchronies: An event-related brain potential study. Psychophysiology, 32, 177-190.

Astésano, C., Besson, M., \& Alter, K. (2004). Brain potentials during semantic and prosodic processing in French. Cognitive Brain Research, 18, 172-184.

Baayen, R. H., Piepenbrock, R., \& Van Rijn, H. (1993). The CELEX lexical database [CD-ROM]. Linguistic Data Consortium. Philadelphia, PA: University of Pennsylvania.

Birch, S., \& Clifton, C. (1995). Effects of varying focus and accenting of adjuncts on the comprehension of utterances. Journal of Memory and Language, 27, 571-588.

Bögels, S., Schriefers, H., Vonk, W., Chwilla, D. J., \& Kerkhofs, R. (2010). The interplay between prosody and syntax in sentence processing: The case of subject- and object-control verbs. Journal of Cognitive Neuroscience, 22, 1036-1053.

Bornkessel, I., \& Schlesewsky, M. (2006). The extended argument dependency model: A neurocognitive approach to sentence comprehension across languages. Psychological Review, 113, 787-821.

Comrie, B. (1985). Reflections on subject and object control. Journal of Semantics, 4, 47-65.
Corpus Gesproken Nederlands. Version 2.0 (2006). Retrieved 13 May 2008. www.inl.nl/nl/corpora/ corpus-gesproken-nederlands-(cgn).

Dahan, D., Tanenhaus, M. K., \& Chambers, C. G. (2002). Accent and reference resolution in spoken-language comprehension. Journal of Memory and Language, 47, 292-314.

Eckstein, K., \& Friederici, A. D. (2005). Late interaction of syntactic and prosodic processes in sentence comprehension as revealed by ERPs. Cognitive Brain Research, 25, 130-143.

Eckstein, K., \& Friederici, A. D. (2006). It's early: Event-related potential evidence for initial interaction of syntax and prosody in speech comprehension. Journal of Cognitive Neuroscience, 18, 1696-1711.

Ferreira, F., Bailey, K. G. D., \& Ferraro, V. (2002). Good-enough representations in language comprehension. Current Directions in Psychological Science, 11, 11-15.

Gussenhoven, C. (1999). On the limits of focus projection in English. In P. Bosch \& R. van der Sandt (Eds.), Focus: Linguistic, cognitive, and computational perspectives (pp. 43-55). Cambridge, MA: University Press.

Hagoort, P., \& Brown, C. (1994). Brain responses to lexical ambiguity resolution and parsing. In K. Rayner, C. Clifton, \& L. Frazier (Eds.), Perspectives on sentence processing (pp. 45-80). Hillsdale, NJ: Erlbaum.

Heim, S., \& Alter, K. (2006). Prosodic pitch accents in language comprehension and production: ERP data and acoustic analyses. Acta Neurobiologiae Experimentalis, 66, 55-68.

Heim, S., \& Alter, K. (2007). Focus on focus: The brain's electrophysiological response to focus particles and accents in German. In A. Spath (Ed.), Language, context and cognition: Interfaces and interface conditions. Berlin: Walter de Gruyter.

Hruska, C., \& Alter, K. (2004). Prosody in dialogues and single sentences: How prosody can influence speech perception. In A. Steube (Ed.), Language, context and cognition. Information structure: Theoretical and empirical aspects (pp. 211-226). Berlin: Walter de Gruyter.

Johnson, S. M., Clifton, C., Breen, M., \& Morris, J. (2003). An ERP investigation of prosodic and semantic focus. Journal of Cognitive Neuroscience, 14(Suppl.), 174. 
Kerkhofs, R., Vonk, W., Schriefers, H., \& Chwilla, D. J. (2007). Discourse, syntax, and prosody: The brain reveals an immediate interaction. Journal of Cognitive Neuroscience, 19, 1421-1434.

Kerkhofs, R., Vonk, W., Schriefers, H., \& Chwilla, D. J. (2008). Sentence processing in the visual and auditory modality: Do comma and prosodic break have parallel functions? Brain Research, 1224, 102-118.

Kjelgaard, M. M., \& Speer, S. R. (1999). Prosodic facilitation and interference in the resolution of temporary syntactic closure ambiguity. Journal of Memory and Language, 40, 153-194.

Magne, C., Astésano, C., Lacheret-Dujour, A., Morel, M., Alter, K., \& Besson, M. (2005). On-line processing of "pop-out" words in spoken French dialogues. Journal of Cognitive Neuroscience, 17, 740-756.

Mak, W. M., Vonk, W., \& Schriefers, H. (2002). The influence of animacy on relative clause processing. Journal of Memory and Language, 47, 50-68.

Pannekamp, A., Toepel, U., Alter, K., Hahne, A., \& Friederici, A. D. (2005). Prosody-driven sentence processing: An event-related brain potential study. Journal of Cognitive Neuroscience, 17, 407-421.

Pauker, E., Itzhak, I., Baum, S. R., \& Steinhauer, K. (submitted) Co-operating and conflicting prosody in spoken English garden path sentences: Evidence from event-related brain potentials. Journal of Cognitive Neuroscience.

Pickering, M. J., Traxler, M. J., \& Crocker, M. W. (2000). Ambiguity resolution in sentence processing: Evidence against frequency-based accounts. Journal of Memory and Language, 43, 447-475.

Pynte, J., \& Prieur, B. (1996). Prosodic breaks and attachment decisions in sentence parsing. Language and Cognitive Processes, 11, 165-191.

Roll, M., Horne, M., \& Lindgren, M. (2009). Left-edge boundary tone and main clause verb effects in syntactic processing in embedded clauses: An ERP study.Journal of Neurolinguistics, 22, 55-73.

Roll, M., Horne, M., \& Lindgren, M. (2011). Activating without inhibiting: Left-edge boundary tones and syntactic processing Journal of Cognitive Neuroscience, 23, 1170-1179.

Steinhauer, K., Alter, K., \& Friederici, A. D. (1999). Brain potentials indicate immediate use of prosodic cues in natural speech processing. Nature Neuroscience, 2, 191-196.

Stolterfoht, B., Friederici, A. D., Alter, K., \& Steube, A. (2007). Processing focus structure and implicit prosody during reading: Differential ERP effects. Cognition, 104, 565-590.

Toepel, U., Pannekamp, A., \& Alter, K. (2007). Catching the news: Processing strategies in listening to dialogs as measured by ERPs. Behavioral and Brain Functions, 3, 53 .

Vissers, C. Th. W. H., Kolk, H. H. J., Van de Meerendonk, N., \& Chwilla, D. J. (2008). Monitoring in language perception: Evidence from ERPs in a picture-sentence matching task. Neuropsychologia, 46, 967-982.

Warren, P., Grabe, E., \& Nolan, F. (1995). Prosody, phonology and parsing in closure ambiguities. Language and Cognitive Processes, 10, 457-486. 